\title{
Chronic Toxicity of Binary-Metal Mixtures of Cadmium and Zinc to Daphnia magna
}

\author{
Edgar Pérez \\ Loyola University Chicago \\ Tham C. Hoang \\ Loyola University Chicago, thoang@luc.edu
}

Follow this and additional works at: https://ecommons.luc.edu/ies_facpubs

Part of the Environmental Sciences Commons, and the Toxicology Commons

\section{Author Manuscript}

This is a pre-publication author manuscript of the final, published article.

\section{Recommended Citation}

Pérez, Edgar and Hoang, Tham C.. Chronic Toxicity of Binary-Metal Mixtures of Cadmium and Zinc to Daphnia magna. Environmental Toxicology and Chemistry, 36, 10: 2739-2749, 2017. Retrieved from Loyola eCommons, School of Environmental Sustainability: Faculty Publications and Other Works,

http://dx.doi.org/10.1002/etc.3830

This Article is brought to you for free and open access by the Faculty Publications and Other Works by Department at Loyola eCommons. It has been accepted for inclusion in School of Environmental Sustainability: Faculty Publications and Other Works by an authorized administrator of Loyola eCommons. For more information, please contactecommons@luc.edu. c) () $\odot$

This work is licensed under a Creative Commons Attribution-Noncommercial-No Derivative Works 3.0 License. (C) SETAC 2017 


\title{
Environmental Toxicology and Chemistry
}

\author{
Environmental Toxicology
}

CHRONIC TOXICITY OF BINARY-METAL MIXTURES OF CADMIUM AND ZINC TO

DAPHNIA MAGNA

Edgar Pérez and Tham C. Hoang

Environ Toxicol Chem., Accepted Article • DOI: 10.1002/etc.3830

\section{Accepted Article}

"Accepted Articles" are peer-reviewed, accepted manuscripts that have not been edited, formatted, or in any way altered by the authors since acceptance. They are citable by the Digital Object Identifier (DOI). After the manuscript is edited and formatted, it will be removed from the "Accepted Articles" Web site and published as an Early View article. Note that editing may introduce changes to the manuscript text and/or graphics which could affect content, and all legal disclaimers and ethical guidelines that apply to the journal pertain. SETAC cannot be held responsible for errors or consequences arising from the use of information contained in these manuscripts.

This article is protected by copyright. All rights reserved 
Environmental Toxicology

Environmental Toxicology and Chemistry DOI 10.1002/etc.3830

E. Pérez and T.C. Hoang

Chronic toxicity of metal mixtures to D. magna

CHRONIC TOXICITY OF BINARY-METAL MIXTURES OF CADMIUM AND ZINC TO DAPHNIA MAGNA

\author{
Edgar Pérez ${ }^{1}$ and Tham C. Hoang ${ }^{1 *}$ (iD)
}

${ }^{1}$ Institute of Environmental Sustainability, Loyola University Chicago, Chicago, Illinois, USA

*Address correspondence to:

E-Mail: thoang@luc.edu

This article contains online-only Supplemental Data

This article is protected by copyright. All rights reserved

Submitted 30 November 2016; Returned for Revision 9 January 2017; Accepted 19 April 2017

This article is protected by copyright. All rights reserved 


\begin{abstract}
The present study characterized the chronic effect of binary-metal mixtures of cadmium $(\mathrm{Cd})$ and zinc ( $\mathrm{Zn}$ ) on Daphnia magna. The titration design was chosen to characterize the 21-d chronic effects of the binary-metal mixtures on survival, growth, reproduction, and metal accumulation in D. magna. Using this design, increasing concentrations of $\mathrm{Zn}(10,20,40,80,120,160$ and $200 \mu \mathrm{g} / \mathrm{L}$ ) were titrated against a constant concentration of $1.5 \mu \mathrm{g} / \mathrm{L} \mathrm{Cd}$. The results demonstrated that $\mathrm{Cd}$ was highly toxic to D. magna. In a mixture with $\mathrm{Cd}$ and $\mathrm{Zn}$, sublethal concentrations of 10 and $20 \mu \mathrm{g} / \mathrm{L}$ Zn were insufficient to protect D. magna from chronic Cd toxicity, while mixtures containing 40,80 , and $120 \mu \mathrm{g} / \mathrm{L} \mathrm{Zn}$ provided strong protective effects to $D$. magna at all endpoints and resulted in less-than-additive effects. At higher $\mathrm{Zn}$ concentrations, such as 160 and $200 \mu \mathrm{g} / \mathrm{L}, \mathrm{Zn}$ appeared to contribute to the toxicity. The less-than-additive effects observed in the $\mathrm{Cd}-\mathrm{Zn}$ mixture can be explained by the decrease in body $\mathrm{Cd}$ concentration when increasing $\mathrm{Zn}$ concentration in the exposure media. Embryos analyzed for morphological alterations in the CdZn mixtures demonstrated severe developmental defects. The effect of $\mathrm{Cd}$ on undeveloped embryos while both $\mathrm{Zn}$ and $\mathrm{Cd}$ are present in the organisms raises a question of whether the competitive binding mechanism of $\mathrm{Zn}$ and $\mathrm{Cd}$ is still happening at the cellular level in the organisms. The results of the present study are useful for the development of the Biotic Ligand Model and environmental quality guidelines for metal mixtures. This article is protected by copyright. All rights reserved
\end{abstract}

Keywords: metal toxicity; metal mixture toxicity; reproductive toxicity; embryotic development; metal mixture uptake; Daphnia magna

This article is protected by copyright. All rights reserved 


\section{INTRODUCTION}

In nature, aquatic ecosystems are generally contaminated with mixtures of multiple metals. Studies have investigated metal mixture effects for decades [1] but a great portion of those studies have only invested large efforts in understanding acute toxicity. For example, in recent meta-analyses conducted by Norwood et al. [2] and Vijver et al. [3] only 35\% and 9\% of the studies respectively, reported chronic toxicity. A recent metal mixture evaluation conducted by Meyer et al. [1] indicated the need for chronic mixture studies since the lack of chronic toxicity data in the literature makes it difficult to arrive at meaningful deductions concerning the interactions of metals in long-term exposures. As a result, studies investigating chronic toxicity of metal mixtures at sublethal concentrations are essential to improve scientific understanding of interactions between metals and organisms and long-term metal mixture toxicity.

Of interest in the present study is the chronic mixture toxicity of cadmium $(\mathrm{Cd})$ and zinc (Zn). Cadmium and $\mathrm{Zn}$ are two metals that are commonly found in aquatic environments [4] especially near metal-mining and/or metal-processing facilities. Cadmium is a trace non-essential metal that has no biological function and is very toxic to aquatic life $[5,6]$. Cadmium enters the aquatic environment from both natural sources (chemical weathering of soils and bedrock) and anthropogenic sources (mining, leachate from contaminated sites, and industrial wastewater discharges etc.) [7]. Zinc on the other hand, is an essential nutrient for biotic life, but is also toxic at high concentrations $[8,9]$. Zinc is introduced into aquatic environments through various anthropogenic (manufacturing of brass and other alloys, automobile equipment, medical tools, domestic appliances, pharmaceuticals, construction, and synthesis of animal feed and fertilizers), and natural sources (chemical weathering of rocks and minerals) [10].

This article is protected by copyright. All rights reserved 
The acute toxicity of metal mixtures on aquatic organisms is not consistent. Studies examining the effect of $\mathrm{Cd}$ and $\mathrm{Zn}$ mixtures across Daphnia species, and freshawater shrimp and copepods have shown additive (noninteractive) and nonadditive (interactive) effects [2, 11-13]. Norwood et al. [2] proposed that the variability in organism responses might just be due to concentration-dependent, and inter/intraspecific species differences in sensitivity. In addition, random variability in organism responses may have led to inaccurate interpretation of mixture toxicity assessments as demonstrated by De Laender et al. [14]. If both metal alone and metal mixture toxicity tests are not simultaneously conducted, truly nonadditive (less-than-additive or greater-than-additive) effects might be misinterpreted as additive effects, or vice versa. As a result, in the present study, it was crucial and essential that both $\mathrm{Zn}$ alone and $\mathrm{Cd}-\mathrm{Zn}$ mixture tests were conducted concurrently to avoid misleading toxicity interpretations.

The objective of the present study is to characterize the chronic effect of $\mathrm{Cd}$ and $\mathrm{Zn}$ mixtures using a titration experimental design as used by Meyer et al. [13]. The measured endpoints include: survival, reproduction, growth, and metal accumulation in D. magna when exposed to $\mathrm{Zn}$ alone and to mixtures of $\mathrm{Cd}-\mathrm{Zn}$ at sublethal concentrations.

\section{MATERIALS AND METHODS}

\section{Test organisms}

Laboratory cultured Daphnia magna from the Ecotoxicology and Risk Assessment Laboratory at the Loyola University Chicago's Institute of Environmental Sustainability (IES) were utilized in this study. Daphnia magna cultures were maintained in 1L glass beakers (30 per beaker). Beakers were filled with 900-1000 $\mathrm{ml}$ reconstituted moderately hard water (MHW) made from $16-18 \mathrm{M} \Omega$ MilliQ water and laboratory grade chemicals $\left(\mathrm{CaSO}_{4} .2 \mathrm{H}_{2} \mathrm{O}, \mathrm{MgSO}_{4}\right.$, $\mathrm{NaHCO}_{3}$, and $\mathrm{KCl}$ ) based on the U.S.EPA method for chronic toxicity testing [15]. The water This article is protected by copyright. All rights reserved 
quality measures for the culture media were as follows: hardness ranged from 80 to $84 \mathrm{mg} / \mathrm{L}$ as $\mathrm{CaCO}_{3}$, alkalinity ranged from 55 to $61 \mathrm{mg} / \mathrm{L}$ as $\mathrm{CaCO}_{3}, \mathrm{pH}$ ranged from 7.19 to 7.89 , and dissolved oxygen (DO) ranged from 6.87 to $8.32 \mathrm{mg} / \mathrm{L}$. Cultures were maintained at a temperature ranging from 21.2 to $25.6^{\circ} \mathrm{C}$ and at a light:dark photoperiod of 16h:8h. Daphnia magna culture water was changed on Mondays, Wednesdays, and Fridays. Dissolved oxygen, $\mathrm{pH}$, and temperature were recorded following subsequent water changes. Dissolved oxygen and temperature were measured with a DO instrument: model YSI 550A, and pH was measured with a Fisher Scientific accumet portable laboratory meter: model AP110. Cultured D. magna were fed $6 \mathrm{ml}$ of an algae suspension (Raphidocelis subcapitata, formerly known as Selenastrum capricornutum) at a concentration of $3 \times 10^{7}$ cells $/ \mathrm{ml}$, and $3 \mathrm{ml}$ YCT (a food suspension of yeast, cereal leaves and trout chow) at a concentration of 1.7- $1.9 \mathrm{mg}$ solids/L daily. The algae and YCT were cultured and prepared in the Loyola University Chicago’s Ecotoxicology and Risk Assessment Laboratory based on the U.S. EPA Method [15].

Metal alone and binary-metal toxicity tests

The titration method was used in this study to characterize the chronic toxicity of Cd-Zn mixtures on D. magna. The titration design was chosen because it affords the detection of graded changes in organism responses, across graded increases in metal concentrations [13]. Using this design, nominal $\mathrm{Cd}$ concentration was kept constant at $1.5 \mu \mathrm{g} / \mathrm{L}$ across all treatments and nominal Zn concentrations varied (10, 20, 40, 80, 120, 160 and $200 \mu \mathrm{g} / \mathrm{L})$. Concentrations of $\mathrm{Cd}$ and $\mathrm{Zn}$ were chosen based on screening chronic toxicity tests conducted in our laboratory (unpublished data). A control (MHW) was also used. To compare with the mixture effect, a chronic Zn alone test with concentrations equal to the $\mathrm{Zn}$ concentrations in the mixture test was conducted. A twenty-one day (21) static renewal toxicity test method was used in the present study [16]. To This article is protected by copyright. All rights reserved 
avoid potential interference of organism health effect, the $\mathrm{Zn}$ alone and mixture tests were conducted simultaneously using neonate $D$. magna coming from the same batch $\left(5^{\text {th }}\right.$ brood). Tests were conducted with $48 \mathrm{~h}$ test solution renewals in an aquatic toxicology testing room located in the Loyola IES. The aquatic toxicology testing room was set at a temperature of $21^{\circ} \mathrm{C}$ and a photoperiod of light:dark $=16 \mathrm{~h}: 8 \mathrm{~h}$. The exposure media were prepared from stock solutions that were prepared from lab grade metal salts $\left(\mathrm{CdSO}_{4}\right.$ and $\left.\mathrm{ZnCl}_{2}\right)$. The $\mathrm{Zn}$ alone toxicity test consisted of 7 treatments with 4 replicates each while the binary-metal toxicity test consisted of 8 treatments with 4 replicates each which included a Cd alone treatment. Replicates were comprised of $600 \mathrm{ml}$ polypropylene cups containing 10 neonate D. magna $(<24 \mathrm{~h}$ old $)$ in $200 \mathrm{ml}$ of test solution from day 0 to day 10 , and $350 \mathrm{ml}$ test solution from day 11 to day 21 to compensate for D. magna growth.

Due to the nature of the study, organisms grew over time, therefore, varying amounts of a suspension of Raphidocelis subcapitata with a concentration of $3 \times 10^{7}$ cells $/ \mathrm{ml}$ and YCT of a concentration of $1.7-1.9 \mathrm{mg}$ solids/L were fed daily. Food rations were adjusted depending on the feeding rate of the organisms. Feeding rate was low when organisms were small but increased when the organisms grew bigger (Table 1, Supplemental Data,).

Mortality was recorded daily to determine effects of $\mathrm{Zn}$ and $\mathrm{Cd}-\mathrm{Zn}$ mixture on survival of D. magna. A D. magna was considered dead if no mobility was observed after gentle probing with a pipette, and if no organ movements were observed using a 6 X Bausch \& Lomb magnifier (Bausch \& Lomb). Dead organisms were removed from the test chambers and discarded. Reproductive output was also observed daily once $D$. magna became sexually mature and began reproducing. All neonates, both dead and alive, were separately counted, recorded, removed from the test chambers, and discarded. The same procedure was used if any undeveloped This article is protected by copyright. All rights reserved 
embryos were observed in the test chambers. The embryos were collected in a $30 \mathrm{~mL}$ polypropylene beaker for morphological examination with a Zeiss ZEN imaging software model SteREO Discovery.v12. Reproductive rate per day was calculated as a ratio of number of neonates produced in a day to the number of surviving adults on the same day. Proportion of dead neonates was calculated as a percentage of number of dead neonates observed in a day over the total number of dead and live neonates counted on the same day. Proportion of undeveloped embryos was calculated as a percentage of the total number of embryos observed in a day over the total number of dead, live neonates, and undeveloped embryos counted on the same day.

Twenty-four hours prior to the termination of the experiment, $50 \mathrm{~mL}$ polypropylene digestion tubes were labelled, placed in a Fisher Drying Oven, and dried at $60^{\circ} \mathrm{C}$. At the end of the experiment, all surviving adults in each test chamber were collected, transferred into a respectively labelled digestion tube, and carefully rinsed three times with DI water. All organisms in each replicate were jointly weighed in the digestion tube with a Metro Toledo Balance Model XS64, and their wet-weight was recorded. Organisms were then dried in the same oven at $60^{\circ} \mathrm{C}$ for $48 \mathrm{~h}$ and reweighed to determine dry weight. The average dry weight for each individual organism was obtained by dividing the total weight in each replicate by the number of surviving organisms in that replicate.

\section{Water quality and chemical analyses}

Two 190L batches of MHW were prepared in the Ecotoxicology and Risk Assessment Lab during the $\mathrm{Cd}-\mathrm{Zn}$ mixtures study as described in the test organism section above. Water quality measures for both toxicity tests ( $\mathrm{Zn}$ alone and $\mathrm{Cd}-\mathrm{Zn}$ mixtures) were taken once a week on days $0,7,14$, and 21. Dissolved oxygen and temperature were measured with a dissolved oxygen instrument: model YSI 550A. The $\mathrm{pH}$ was measured with a Fisher Scientific accumet This article is protected by copyright. All rights reserved 
portable laboratory meter: model AP110. Hardness and alkalinity were measured by titration methods (Methods 2320, 2340) [17]. Hardness was titrated against $0.01 \mathrm{M}$ ethylenediaminetetraacetic acid. Alkalinity was titrated against $0.02 \mathrm{~N} \mathrm{H}_{2} \mathrm{SO}_{4}$. Water samples for total and dissolved metals, cations and anions were also collected weekly and at the same time with collection of water samples for water quality measurements. For each sample type, approximately $14 \mathrm{ml}$ of test water was collected into a $15 \mathrm{ml}$ polypropylene sample vial. Total metal samples were taken directly from the test water, but dissolved metal and cation and anion samples were filtered through Whatman polyvinyldifluoride filters with a pore diameter of $0.45 \mu \mathrm{m}$. Water samples for total and dissolved metals were preserved with one drop of concentrated nitric acid, and refrigerated for later analysis. In addition, approximately $25 \mathrm{ml}$ of test water was filtered through a new filter of the same filter type used for dissolved metal and cations and anions and collected into a $30 \mathrm{~mL}$ amber glass bottle for analysis of dissolved organic carbon (DOC). To determine body metal content and accumulation, surviving daphnids were digested with $\mathrm{HNO}_{3}$ based on U.S. EPA Method 3050B [18]. Digested solutions were used for analysis of metal content in surviving daphnids.

Analyses of total metal, dissolved metal, and cation concentrations were conducted using a 300X NexION ICP-MS (Perkin Elmer). Concentrations of DOC were analyzed with a TOC-L CSH analyzer (Shimazu). An 881 Compact Ion Chromatography (Metrohm USA) was used to analyze concentrations of anions. Results of the QC samples showed recovery of 90 to $115 \%$ for total and dissolved metals; 95 to $113 \%$ for DOC, and 90 to $110 \%$ for anions.

\section{Data analyses}

For $\mathrm{Zn}$ alone test, data were compared for statistically significant differences between control and exposure treatments. For the mixture test in addition to comparisons between control This article is protected by copyright. All rights reserved 
and exposure treatments, data were also compared for statistically significant differences between $\mathrm{Cd}$ alone and $\mathrm{Cd}-\mathrm{Zn}$ mixture treatments.

A one-way analysis of variance (ANOVA), along with a Tukey's honestly significant difference (HSD) multiple comparisons test was used to detect treatment differences within each endpoint. Differences across treatments of $\mathrm{Zn}$ alone and their corresponding $\mathrm{Cd}-\mathrm{Zn}$ mixtures (e.g., treatment 1 for $\mathrm{Zn}$ alone and treatment 2 for $\mathrm{Cd}-\mathrm{Zn}$ mixture) were also analyzed using a one-way ANOVA. To test for interaction effects of Cd and Zn, a two-way ANOVA was used, treating metal exposure type as a factor ( $\mathrm{Zn}$ alone or its corresponding $\mathrm{Cd}-\mathrm{Zn}$ mixture) and the concentrations of zinc as another factor. To meet the requirements of homogenous variance and normal distribution, an arcsine square root transformation method was used for mortality, the proportion of dead neonates and undeveloped embryos data. Square root transformation method was used for total neonates, total live neonates, and reproductive rate data. Growth data were not transformed because the data met the requirements of homogenous variance and normal distribution. Time to first brood data; however were analyzed using the non-parametric method.

The one-way and two-way ANOVAs were conducted with R-Program (Ver 3.1.1). Comparison for significant difference between the model coefficients of metal uptake was conducted using SAS (Ver 9.3.1). An effect with a $p<0.05$ is considered significant.

\section{RESULTS}

\section{Water chemistry}

The average measured total and dissolved metal concentrations deviated approximately 0-15\% from the nominal concentrations (except for the two lowest $\mathrm{Zn}$ concentrations) in the $\mathrm{Cd}$ Zn mixtures and Zn alone treatments (Table 2, Supplemental Data). To be convenient, nominal concentrations are used to present the test treatments. However, measured dissolved $\mathrm{Zn}$ This article is protected by copyright. All rights reserved 
concentrations in the test water of $\mathrm{Zn}$ alone and $\mathrm{Cd}-\mathrm{Zn}$ mixture tests were used for modeling the relationship between water $\mathrm{Zn}$ concentration and body $\mathrm{Zn}$ and $\mathrm{Cd}$ concentrations (Fig. 11).

The average and standard deviation of hardness, alkalinity, $\mathrm{pH}, \mathrm{DO}$, and temperature for the $\mathrm{Zn}$ alone test were: $88.7 \pm 7.18 \mathrm{mg} / \mathrm{L}$ as $\mathrm{CaCO}_{3}(\mathrm{n}=12), 61.5 \pm 3.97 \mathrm{mg} / \mathrm{L}$ as $\mathrm{CaCO}_{3}(\mathrm{n}=12)$, $7.6 \pm 0.16(\mathrm{n}=26), 7.3 \pm 0.24 \mathrm{mg} / \mathrm{L}(\mathrm{n}=26)$, and $22.6 \pm 0.40^{\circ} \mathrm{C}(\mathrm{n}=26)$ respectively. Those same water quality parameters for the $\mathrm{Cd}-\mathrm{Zn}$ mixture test were: $90.6 \pm 4.52 \mathrm{mg} / \mathrm{L}$ as $\mathrm{CaCO}_{3}(\mathrm{n}=12)$, $60.4 \pm 3.85 \mathrm{mg} / \mathrm{L}$ as $\mathrm{CaCO}_{3}(\mathrm{n}=12) 7.7 \pm 0.15(\mathrm{n}=26), 7.7 \pm 0.34 \mathrm{mg} / \mathrm{L}(\mathrm{n}=26)$, and $22.3 \pm$ $0.45^{\circ} \mathrm{C}(\mathrm{n}=26)$ respectively. Although organic carbon was not added into the test water, an average measurement of DOC concentrations of $4.44 \mathrm{mg} / \mathrm{L}$ for $\mathrm{Zn}$ alone and $4.21 \mathrm{mg} / \mathrm{L}$ for CdZn mixture tests were found (Table 3, Supplemental Data). The DOC was suspected as coming from the fed diet of D. magna (YCT and algae) and our DOC analysis on the YCT samples confirmed this suspicion. The average concentration of $\mathrm{Cl}^{-}, \mathrm{SO}_{4}{ }^{2-}, \mathrm{F}^{-}, \mathrm{PO}_{4}{ }^{3-}$, and $\mathrm{Br}^{-}$of $\mathrm{Zn}$ alone and Cd-Zn mixture tests ranged from, 4.1 to $6.2 \mathrm{mg} / \mathrm{L}, 157$ to $175 \mathrm{mg} / \mathrm{L}, 0.6$ to $0.7 \mathrm{mg} / \mathrm{L}$, not detected to $0.26 \mathrm{mg} / \mathrm{L}$, and not detected to $1.3 \mathrm{mg} / \mathrm{L}$, respectively (Table 4, Supplemental Data). The average concentration range of $\mathrm{Na}^{+}, \mathrm{K}^{+}, \mathrm{Ca}^{2+}$, and $\mathrm{Mg}^{2+}$ of $\mathrm{Zn}$ alone and $\mathrm{Cd}-\mathrm{Zn}$ mixture tests were $25.6-33.4,2.1-3.0,12.4-14.4$, and $11.9-14.3 \mathrm{mg} / \mathrm{L}$, respectively. Survival

The average 21-d cumulative percent mortality in the Cd-Zn mixtures containing 40, 80, or $120 \mu \mathrm{g} / \mathrm{L} \mathrm{Zn}$ were significantly lower in comparison to $\mathrm{Cd}$ alone $(p<0.01)$ while the $\mathrm{Cd}-\mathrm{Zn}$ mixtures containing 160 and $200 \mu \mathrm{g} / \mathrm{L}$ Zn were significantly higher $(p<0.01)$ (Fig. 1). There was no statistically significant difference in cumulative mortality between the $\mathrm{Cd}-\mathrm{Zn}$ mixtures containing 10 and $20 \mu \mathrm{g} / \mathrm{L} \mathrm{Zn}$ and $\mathrm{Cd}$ alone. This indicates that when $\mathrm{Zn}$ is present at low concentrations, such as 10 and $20 \mu \mathrm{g} / \mathrm{L}$ in a mixture with $1.5 \mu \mathrm{g} / \mathrm{L} \mathrm{Cd}$, mortality remains high and This article is protected by copyright. All rights reserved 
the Cd effect on survival is still pronounced. However, as $\mathrm{Zn}$ concentrations increase in the mixtures $(40,80$, and $120 \mu \mathrm{g} / \mathrm{L})$, mortality significantly decreases, reaching the lowest mortality at $80 \mu \mathrm{g} / \mathrm{L}$ (Fig. 1). Therefore, at a sufficient concentration, Zn protects D. magna from the chronic toxicity of $\mathrm{Cd}$, an evidence of a less-than-additive effect. However, given that the cumulative mortality was significantly different between $\mathrm{Cd}-\mathrm{Zn}$ mixtures and $\mathrm{Cd}$ alone at higher Zn concentrations (i.e., 160, $200 \mu \mathrm{g} / \mathrm{L}$ ), Zn accumulation likely exceeded the threshold for $\mathrm{Zn}$ caused toxicity to D. magna and thereby caused most or all of the observed toxicity.

In comparing the cumulative percent mortality of $\mathrm{Zn}$ alone with its corresponding $\mathrm{Cd}-\mathrm{Zn}$ mixture, the treatments containing 10,20 , or $40 \mu \mathrm{g} / \mathrm{L} \mathrm{Zn}$ were found to be significantly different $(p<0.05)$ (Fig. 1). At these concentrations of $\mathrm{Zn}$ alone, there was no mortality or non-significant difference in mortality between the control and $\mathrm{Zn}$ alone treatments (Fig. 1). These results signify that the toxicity in those $\mathrm{Cd}-\mathrm{Zn}$ mixtures would be due to $\mathrm{Cd}$ exposure. There was no statistically significant difference found in mortality between $\mathrm{Zn}$ alone and its corresponding $\mathrm{Cd}$ Zn mixture at the higher Zn concentrations (80 to $200 \mu \mathrm{g} / \mathrm{L}$ ). However, given that the cumulative mortality in the $\mathrm{Zn}$ alone treatments containing 80 and $120 \mu \mathrm{g} / \mathrm{L}$ were not significantly different from the control; the toxicity observed in the corresponding $\mathrm{Cd}-\mathrm{Zn}$ mixtures might also have been due to $\mathrm{Cd}$ exposure. At higher $\mathrm{Zn}$ concentrations (160 and $200 \mu \mathrm{g} / \mathrm{L}$ ), the toxicity observed in the $\mathrm{Cd}-\mathrm{Zn}$ mixtures was likely due to $\mathrm{Zn}$ exposure because there was no significant difference in cumulative mortality between $\mathrm{Zn}$ alone and its corresponding $\mathrm{Cd}-\mathrm{Zn}$ mixture.

\section{Reproduction}

Total neonates, live neonates, and reproductive rates: The effects of the $\mathrm{Cd}-\mathrm{Zn}$ mixtures on the reproductive effort of $D$. magna are as follows. The total number of neonates $(p<0.05)$ (Fig. 2) and the number of live neonates $(p<0.05)$ (Fig. 3) reproduced by D. magna in the Cd-Zn This article is protected by copyright. All rights reserved 
mixtures containing 40,80 , or $120 \mu \mathrm{g} / \mathrm{L} \mathrm{Zn}$ were significantly higher in comparison to $\mathrm{Cd}$ alone. Similarly, the overall reproductive rate $(p<0.05)$ (Fig. 4$)$, and the live neonate reproductive rate $(p<0.05)$ (Fig. 5) were also significantly higher in the Cd-Zn mixtures containing 40, 80, or $120 \mu \mathrm{g} / \mathrm{L} \mathrm{Zn}$ than in $\mathrm{Cd}$ alone. No other $\mathrm{Cd}-\mathrm{Zn}$ mixture had a significantly higher number of neonates or reproductive rates than that of $\mathrm{Cd}$ alone. These results suggest that $\mathrm{Cd}-\mathrm{Zn}$ mixtures containing 10 and $20 \mu \mathrm{g} / \mathrm{L} \mathrm{Zn}$ are not sufficient to protect $D$. magna from Cd reproductive effect. Daphnia magna in those mixtures did not reproduce neither a higher number of total neonates nor a higher number of living neonates compared to Cd alone (Figs. 2, 3), thereby reflecting the reduction in their respective reproductive rates (Figs. 4, 5). However, increasing $\mathrm{Zn}$ concentrations in the mixtures $(40,80$, and $120 \mu \mathrm{g} / \mathrm{L}$ ) inhibited Cd reproductive effects (evidence of a less-than-additive effect), which translated into a significantly higher number of both total neonates (Fig. 2) and live neonates (Fig. 3). These are represented in the higher overall reproductive rate shown in Figure 4 and the higher live neonate reproductive rate reflected in Figure 5. On the other hand, in mixtures containing higher $\mathrm{Zn}$ concentrations of 160 or $200 \mu \mathrm{g} / \mathrm{L}$, less-than-additive effects were not observed. Interestingly, only the Cd-Zn mixture containing $200 \mu \mathrm{g} / \mathrm{L} \mathrm{Zn} \mathrm{had} \mathrm{significantly} \mathrm{lower} \mathrm{number} \mathrm{of} \mathrm{both} \mathrm{total} \mathrm{neonates} \mathrm{(} p<0.05$ ) (Fig. 2), and living neonates $(p<0.05)$ (Fig. 3) in comparison to $\mathrm{Cd}$ alone. Again at $\mathrm{Zn}$ concentrations of 160 and $200 \mu \mathrm{g} / \mathrm{L}, \mathrm{Zn}$ accumulation likely exceeded the threshold for Zn-caused toxicity to D. magna and thereby caused most or all of the observed toxicity. Similar to the survival results, the reproduction results also show less-than-additive effect of $\mathrm{Cd}-\mathrm{Zn}$ mixtures when the $\mathrm{Zn}$ concentrations were sufficient but did not exceed the threshold for Zn-caused impairment.

The total number of neonates and the overall reproductive rate in $\mathrm{Zn}$ alone treatments containing $10,20,40$, or $80 \mu \mathrm{g} / \mathrm{L}$ showed no significant difference with the control (Figs. 2, 4). This article is protected by copyright. All rights reserved 
Similarly, but not quite entirely, $\mathrm{Zn}$ alone concentrations of 10,20 , or $40 \mu \mathrm{g} / \mathrm{L}$ were found to be non-toxic to D. magna reproduction of live neonates (Fig. 3) and $\mathrm{Zn}$ alone concentrations of 10, 20,40 , or $80 \mu \mathrm{g} / \mathrm{L}$ were found to be non-toxic on the live neonate reproductive rate (Fig. 5). On the other hand, treatments containing higher $\mathrm{Zn}$ alone concentrations, such as 120,160 , or $200 \mu \mathrm{g} / \mathrm{L} \mathrm{Zn}$ were found to be toxic to both D. magna's reproduction of total neonates (Fig. 2) and live neonates (Fig. 3), since those treatments contained a significantly lower number of live neonates than the control. Additionally, the overall reproductive rate in $\mathrm{Zn}$ alone did not reveal toxic manifestations in any treatment, except at the highest $\mathrm{Zn}$ alone concentration $(200 \mu \mathrm{g} / \mathrm{L})$ (Fig. 4). Likewise, in the live neonate reproductive rate, only the $\mathrm{Zn}$ alone treatments containing 120 and $200 \mu \mathrm{g} / \mathrm{L}$ were found to be significantly affected (Fig. 5).

Sublethal Zn alone treatments containing 10,20 , or $40 \mu \mathrm{g} / \mathrm{L}$ had a significantly higher number of total neonates $(p<0.05)$ (Fig. 2), and a significantly higher overall reproductive rate $(p<0.05)$ (Fig. 4) in comparison to their corresponding Cd-Zn mixtures. These results suggest that the reproductive effect observed in those $\mathrm{Cd}-\mathrm{Zn}$ mixtures was due to $\mathrm{Cd}$ exposure. The $\mathrm{Zn}$ alone treatment containing $80 \mu \mathrm{g} / \mathrm{L}$ did not exhibit a significantly higher number of total neonates (Fig. 2), nor a higher overall reproductive rate (Fig. 4) in comparison to its corresponding $\mathrm{Cd}-\mathrm{Zn}$ mixture. In addition, the reproductive effect of $\mathrm{Zn}$ alone was not significantly different from the control. Thus the observed reproductive effects in this mixture were likely still due to $\mathrm{Cd}$ exposure. Higher concentrations of $\mathrm{Zn}$ alone treatments (e.g., 120 and $160 \mu \mathrm{g} / \mathrm{L} \mathrm{Zn)} \mathrm{were} \mathrm{also}$ found to have a significantly higher number of total neonates (Fig. 2) and a higher overall reproductive rate (Fig. 4) than their corresponding Cd-Zn mixtures. The one exception was the $\mathrm{Zn}$ alone treatment at $200 \mu \mathrm{g} / \mathrm{L}$. These results suggest that the observed reproductive effects in

This article is protected by copyright. All rights reserved 
the Cd-Zn mixtures containing 120 and $160 \mu \mathrm{g} / \mathrm{L}$ in Figure 2 were due to a joint effect of both $\mathrm{Cd}$ and $\mathrm{Zn}$, since $\mathrm{Zn}$ alone effects in those treatments were significantly lower than the control.

The results in the analysis of total live neonates (Fig. 3) and the live neonate reproductive rate (Fig. 5) were similar to the results obtained in the analysis of total neonates (Fig. 2) and the overall reproductive rate (Fig. 4). The only difference was that the $\mathrm{Zn}$ alone treatment containing $80 \mu \mathrm{g} / \mathrm{L}$ were found to be significantly lower in comparison to the control when only live neonates were considered (Fig. 3). Moreover, since that same treatment was also found to contain a significantly higher number of live neonates than its corresponding $\mathrm{Cd}-\mathrm{Zn}$ mixture (Fig. 3); the reproductive effect observed in the mixture was due to both $\mathrm{Cd}$ and $\mathrm{Zn}$, a result that was not detected when both dead and live neonates were considered collectively (Fig. 2). Lastly, with respect to the live neonate reproductive rate (Fig. 5), the $\mathrm{Zn}$ alone treatment containing $120 \mu \mathrm{g} / \mathrm{L}$ was significantly lower than the control, signifying that the reproductive effect observed in its corresponding $\mathrm{Cd}-\mathrm{Zn}$ mixture was due to both $\mathrm{Cd}$ and $\mathrm{Zn}$. Again, this was a result that was not detected when total neonates were considered (Fig. 4).

Total dead neonates and undeveloped embryos. The present study shows that except for the treatment containing $200 \mu \mathrm{g} / \mathrm{L} \mathrm{Zn}$, other $\mathrm{Cd}-\mathrm{Zn}$ mixtures had a significantly higher percentage of dead neonates than did the control $(p<0.05)$ (Fig. 6). Moreover, the Cd-Zn mixtures containing 10,20 , or $40 \mu \mathrm{g} / \mathrm{L} \mathrm{Zn}$ had a significantly higher percentage of dead neonates compared to the $\mathrm{Cd}$ alone treatment $(p<0.05)$, whereas $\mathrm{Cd}-\mathrm{Zn}$ mixtures containing higher $\mathrm{Zn}$ concentrations were not (Fig. 6). These results indicate that $\mathrm{Zn}$ did not protect neonate D. magna from Cd toxicity. The percentage of dead neonates observed in the Cd-Zn mixtures containing 10, 20, or $40 \mu \mathrm{g} / \mathrm{L}$ were significantly higher than the percentage of dead neonates observed in their corresponding $\mathrm{Zn}$ alone treatments $(p<0.05)$ (Fig.6). This suggests that $\mathrm{Cd}$ plays an important This article is protected by copyright. All rights reserved 
role in producing effects in those $\mathrm{Cd}-\mathrm{Zn}$ mixtures. At higher $\mathrm{Zn}$ concentrations there was no significant difference in percentage of dead neonates observed in mixtures and their corresponding $\mathrm{Zn}$ alone treatments. This suggests that the role of $\mathrm{Cd}$ in producing effects in these mixtures is not important.

For the percentage of undeveloped embryos, all $\mathrm{Cd}-\mathrm{Zn}$ mixtures and $\mathrm{Cd}$ alone were significantly different from the control with a $p$-value of less than 0.01 and 0.05 , respectively. (Fig. 7). However, no Cd-Zn mixture held a significantly higher percentage of undeveloped embryos in comparison to Cd alone (Fig. 7).

Except for the $80 \mu \mathrm{g} / \mathrm{L} \mathrm{Zn,} \mathrm{all} \mathrm{Cd-Zn} \mathrm{mixtures} \mathrm{had} \mathrm{a} \mathrm{significantly} \mathrm{higher} \mathrm{percentage} \mathrm{of}$ undeveloped embryos in comparison to their corresponding $\mathrm{Zn}$ alone treatments $(p<0.05)($ Fig. 7). These results suggest that the effects observed in the $\mathrm{Cd}-\mathrm{Zn}$ mixtures at low $\mathrm{Zn}$ concentrations (i.e., 10, 20, $40 \mu \mathrm{g} / \mathrm{L} \mathrm{Zn)} \mathrm{were} \mathrm{likely} \mathrm{due} \mathrm{to} \mathrm{Cd} \mathrm{exposure} \mathrm{because} \mathrm{their}$ corresponding $\mathrm{Zn}$ alone treatments did not produce significant differences with the control (Fig. 7). At higher $\mathrm{Zn}$ concentrations, $\mathrm{Zn}$ alone treatments produced a significantly higher percentage of undeveloped embryos than did the control (Fig. 7). These results suggest that the effect observed in mixtures with higher Zn concentrations was due to both metals. Significant impaired reproduction was observed in the $\mathrm{Cd}-\mathrm{Zn}$ mixture with $200 \mu \mathrm{g} / \mathrm{L} \mathrm{Zn}$, and its corresponding Zn alone (Figs. 2, 3). Therefore, no undeveloped embryos were observed in those treatments.

The undeveloped embryos observed in the $\mathrm{Cd}-\mathrm{Zn}$ mixtures were scanned for the presence of developmental obstructions and morphological alterations. A gravid adult D. magna from the laboratory culture was collected and dissected for embryos and used as a control. Compared to the control embryos, the embryos collected from the $\mathrm{Cd}-\mathrm{Zn}$ mixtures revealed several morphological defects that either halted mitotic cell division (cleavage), or disrupted cellular This article is protected by copyright. All rights reserved 
arrangement and organization which likely prevented the development of an embryo beyond stage 5 (Fig. $8 \mathrm{H})$.

Time to first brood. The time to first brood for $\mathrm{Cd}$ alone was significantly earlier $(9.25$ days on average) in comparison to the control (11 days on average) $(p<0.01)$ (Fig. 9). With exception to the $\mathrm{Cd}-\mathrm{Zn}$ mixture containing $20 \mu \mathrm{g} / \mathrm{L} \mathrm{Zn}$, the time to first brood of the other mixture treatments was significantly higher than that of $\mathrm{Cd}$ alone. In addition, there was no significant difference in the time to first brood between $\mathrm{Zn}$ alone and its corresponding $\mathrm{Cd}-\mathrm{Zn}$ mixture except in the treatment containing $200 \mu \mathrm{g} / \mathrm{L} \mathrm{Zn}$, at which the time to first brood for the mixture treatment was also significantly higher than the control. These results indicate that the Cd-Zn mixture containing $200 \mu \mathrm{g} / \mathrm{L} \mathrm{Zn} \mathrm{increased} \mathrm{the} \mathrm{time} \mathrm{to} \mathrm{first} \mathrm{brood} \mathrm{(Fig.} \mathrm{9).}$

Growth effects

The dry weights of the surviving D. magna exposed to Cd-Zn mixtures containing 40, 80 , or $120 \mu \mathrm{g} / \mathrm{L} \mathrm{Zn}$ were significantly higher than the dry weight of surviving organisms in $\mathrm{Cd}$ alone $(p<0.05)$ (Fig. 10). Furthermore, the dry weight of the surviving organisms in the other CdZn mixtures was not significantly higher in comparison to $\mathrm{Cd}$ alone (Fig. 10). Once more, these results imply that $\mathrm{Cd}-\mathrm{Zn}$ mixtures containing 10 and $20 \mu \mathrm{g} / \mathrm{L} \mathrm{Zn}$ were not sufficient to induce protective effects from $\mathrm{Zn}$ to D. magna. However, Cd-Zn mixtures containing higher $\mathrm{Zn}$ concentrations (e.g., 40, 80, and $120 \mu \mathrm{g} / \mathrm{L} \mathrm{Zn}$ ) strongly protected $D$. magna from Cd growth effect, reaching a peak at $80 \mu \mathrm{g} / \mathrm{L}$ (evidence of less-than-additive effects). Conversely, a protective effect from Zn was not observed in the Cd-Zn mixture containing $160 \mu \mathrm{g} / \mathrm{L} \mathrm{Zn}$. This result indicated that $160 \mu \mathrm{g} / \mathrm{L} \mathrm{Zn}$ exceeded the necessary concentration to protect $D$. magna from chronic Cd growth effect.

This article is protected by copyright. All rights reserved 
The dry weights of the daphnids in the Cd-Zn mixtures containing 10, 20, 40, 80, and $120 \mu \mathrm{g} / \mathrm{L} \mathrm{Zn}$ were significantly lower in comparison to the dry weight of their corresponding $\mathrm{Zn}$ alone treatments $(p<0.01)$ (Fig. 10). These same $\mathrm{Zn}$ alone treatments were not significantly different from the control, except for the treatment containing $120 \mu \mathrm{g} / \mathrm{L} \mathrm{Zn}(p<0.05)$ (Fig. 10). Therefore, the growth effects observed in the Cd-Zn mixtures containing 10, 20, 40, and 80 $\mu \mathrm{g} / \mathrm{L}$ $\mathrm{Zn}$ were likely due to $\mathrm{Cd}$ exposure. However, the growth effect observed in the Cd-Zn mixture containing $120 \mu \mathrm{g} / \mathrm{L} \mathrm{Zn}$ was most likely due to both $\mathrm{Cd}$ and $\mathrm{Zn}$, since the dry weight of the organisms in $\mathrm{Zn}$ alone treatment was significantly different from the control. At higher $\mathrm{Zn}$ concentration $(160 \mu \mathrm{g} / \mathrm{L} \mathrm{Zn}), \mathrm{Zn}$ became toxic to the organisms, and the effect observed in the $\mathrm{Cd}-\mathrm{Zn}$ mixture was most likely due to $\mathrm{Zn}$ exposure.

Metal accumulation effects

The measured $\mathrm{Cd}$ concentrations in the body of surviving daphnids exposed to $\mathrm{Cd}$ alone or $\mathrm{Cd}-\mathrm{Zn}$ mixtures were significantly higher than the measured $\mathrm{Cd}$ concentration in control organisms (Fig. 11). The results also showed that as $\mathrm{Zn}$ concentration increased in the exposure media of $\mathrm{Zn}$ alone and $\mathrm{Cd}-\mathrm{Zn}$ mixture tests, $\mathrm{Zn}$ concentration gradually increased in the body of the surviving daphnids, fitting a power function (Fig. 11). Subsequently, a gradual decrease in body $\mathrm{Cd}$ concentrations followed a similar fitting power function (Fig. 11).

The results obtained from the body analysis of the surviving daphnids from $\mathrm{Cd}-\mathrm{Zn}$ mixtures are consistent with the hypothesis that metals compete for binding sites on the biotic ligand. The organisms exposed to $\mathrm{Cd}$ alone accumulated significantly more $\mathrm{Cd}$ than organisms exposed to a mixture of $\mathrm{Cd}-\mathrm{Zn}(p<0.01)$ (Fig 11). These results enforce a strong evidence of a competitive accumulation effect which results in a less-than-additive effect in Cd-Zn mixtures at $\mathrm{Zn}$ concentrations less than $120 \mu \mathrm{g} / \mathrm{L}$. It is also interesting that the coefficient of the uptake model This article is protected by copyright. All rights reserved 
for $\mathrm{Zn}$ alone (75.556) was significantly higher than that for Cd-Zn mixture (52.898) ( $p=0.03)$.

This indicates that body $\mathrm{Zn}$ concentrations of daphnids were higher in $\mathrm{Zn}$ alone treatments than in $\mathrm{Cd}-\mathrm{Zn}$ mixtures. These results suggest an interference of $\mathrm{Cd}$ on $\mathrm{Zn}$ uptake.

\section{DISCUSSION}

In general, the results of the present study are consistent with other literature studies indicating a protective effect of $\mathrm{Zn}$ from Cd toxicity. For example, Meyer et al. [1] found a lessthan-additive toxicity of Cd-Zn mixtures on D. magna. Cañizares-Villanueva et al. [19] reported reduced Cd toxicity on D. magna when $\mathrm{Zn}$ was present in a mixture after biological treatment with suspended cultures of Chlorella vulgaris in a $48 \mathrm{~h}$ assay (less-than-additive). Attar and Maly [20] also documented reduced Cd toxicity on D. magna after acute exposures to Cd-Zn mixtures. Other studies utilizing test organisms such as shrimp, flag fish, minnows, trout, and green algae have also reported less-than-additive toxicity between $\mathrm{Cd}$ and $\mathrm{Zn}$ mixtures [10, 2125]. However, at high $\mathrm{Zn}$ concentrations in the mixtures, $\mathrm{Zn}$ became toxic to the organisms. The less-than-additive or joint toxic effect in $\mathrm{Cd}-\mathrm{Zn}$ mixtures only occurred at certain concentrations of $\mathrm{Zn}$ and must be dependent on water quality characteristics that influence the bioavailability of metals, such as DOC, $\mathrm{pH}$, and hardness. The discussion below is in the context of the water quality characteristics used in the present study.

\section{Less-than-additive effect and competitive uptake}

Overall, results of the present study indicate that at $\mathrm{Zn}$ concentrations less than $160 \mu \mathrm{g} / \mathrm{L}$, the chronic effect of $\mathrm{Cd}-\mathrm{Zn}$ mixture was less-than-additive. When $\mathrm{Zn}$ concentration is sufficient (not toxic when present alone), Zn appeared to protect the organisms from the chronic toxicity of $\mathrm{Cd}$. The mechanisms of metal mixture toxicity is not clearly understood. It is believed that the less-than-additive toxicity of metal mixtures in aquatic organisms is due to the competitive This article is protected by copyright. All rights reserved 
binding mechanism at the biotic ligand [1,26]. Metals that have stronger affinity with the biotic ligand would occupy more binding sites, and therefore, be accumulated more in organisms than other metals that have less affinity with the biotic ligand. In the present study, we found that as Zn concentrations gradually increased in the exposure media of the Cd-Zn mixtures, body $\mathrm{Zn}$ concentration of D. magna subsequently increased, while the body Cd concentration decreased (Fig. 10). This finding supports the competitive binding mechanism of metals at the biotic ligand and agrees with the results published by Komjarova and Blust [27]. Benson et al. [28] also found similar results for acute toxicity with D. magna and Cd-Zn mixtures. The decrease in body $\mathrm{Cd}$ concentration in D. magna when increasing water $\mathrm{Zn}$ concentration explains the less-thanadditive effect of the $\mathrm{Cd}-\mathrm{Zn}$ mixtures. Typically, $\mathrm{Zn}$ produced protective effects against $\mathrm{Cd}$ toxicity to the organisms. The protective effect is more profound when $\mathrm{Zn}$ concentration is sufficient, for example mortality significantly decreased (Fig. 1) and reproduction (Figs. 2, 4)

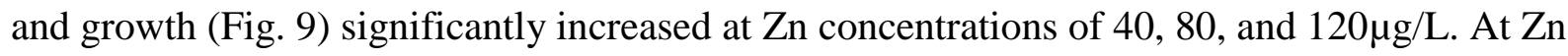
concentrations of 10 or $20 \mu \mathrm{g} / \mathrm{L}$, no significant protective effect of $\mathrm{Zn}$ against $\mathrm{Cd}$ toxicity was found. However, when $\mathrm{Zn}$ concentrations were greater than the necessary concentration to produce protective effects (e.g., $\geq 160 \mu \mathrm{g} / \mathrm{L}$ ), $\mathrm{Zn}$ appeared to contribute to the toxicity. Although body $\mathrm{Cd}$ concentration decreased with increasing water $\mathrm{Zn}$ concentration, it was still significantly higher than the body $\mathrm{Cd}$ concentration of the control organisms. This indicates that $\mathrm{Zn}$ did not completely block $\mathrm{Cd}$ binding to the biotic ligand. As a result, $\mathrm{Cd}$ still entered the organisms and produced certain levels of effects. For example, mortality in the mixtures did not completely decrease to $0 \%$ (mixture treatments 40, 80, $120 \mu \mathrm{g} / \mathrm{L}$ Zn, Fig. 1); reproduction rates of the mixtures were lower compared to the rates of $\mathrm{Zn}$ alone (mixture

This article is protected by copyright. All rights reserved 
treatments 40, 80, $120 \mu \mathrm{g} / \mathrm{L}$ Zn, Figs. 2-5); or more dead neonates and undeveloped eggs were found in the mixtures than in $\mathrm{Zn}$ alone treatments (i.e., 10, 20, $40 \mu \mathrm{g} / \mathrm{L} \mathrm{Zn,} \mathrm{Figs.} \mathrm{6,} \mathrm{7).}$ Early reproduction, food consumption, and possible detoxification mechanism

It is interesting that D. magna in the Cd alone treatment produced neonates earlier than did the control D. magna (Fig. 9) (our coming unpublished results of Cd-Ni study showed similar effects). The fundamental question becomes what is the reason the organisms produced neonates earlier under the Cd alone condition? Yu and Wang [29] reported that up to 44-67\% and $16-47 \%$ of selenium (Se) uptake by D. magna from the aqueous phase and dietary phase, respectively, were lost from the organisms via reproduction. The question of whether the transfer of a significant portion of accumulated Se to her offspring as a detoxification mechanism is still unanswered. In the present study, D. magna might have allocated energy towards earlier reproduction. In addition, when comparing the percentage of dead neonates produced in $\mathrm{Zn}$ alone and its corresponding $\mathrm{Cd}-\mathrm{Zn}$ mixtures; the percentage of dead neonates produced in $\mathrm{Cd}-\mathrm{Zn}$ mixtures containing 10, 20, or $40 \mu \mathrm{g} / \mathrm{L} \mathrm{Zn}$ were significantly higher than those in $\mathrm{Zn}$ alone. Whether early reproduction with its higher percentage of dead neaonates is a mechanism to eliminate the adult's body $\mathrm{Cd}$ is still an unanswered question. Results of the present study did show a significant reduction in body $\mathrm{Cd}$ concentrations in these mixture treatments compared to Cd alone (Fig. 11). Further research is necessary to answer this question.

Our observations also showed that D. magna exposed to $\mathrm{Cd}$ alone did not consume much of the algae fed to them routinely. Consequently, lower reproduction rates and body weights in the $\mathrm{Cd}$ alone treatment compared to the control were observed in the present study. After 21 days of exposure, D. magna exposed to $\mathrm{Cd}$ alone were found to have experienced a $71.4 \%$ decrease in average body weights in comparison to control organisms (Fig. 10). Likewise, Bodar et al. [30] This article is protected by copyright. All rights reserved 
exposed $D$. magna neonates to 1 and $5 \mu \mathrm{g} / \mathrm{L} \mathrm{Cd}$ and found that after 14 days of exposure, the body weights of $D$. magna in both Cd treatments had dropped to approximately $40 \%$ in comparison to the control. Bodar and colleagues [5] reported that Cd directly disrupted feeding behavior and digestive mechanisms, which resulted in altered metabolism, subsequently reducing food consumption. Another study by Jemec et al. [31] also found that Cd concentrations $\geq 0.656 \mu \mathrm{g} / \mathrm{L}$ significantly affected $D$. magna reproduction and survival. Likewise, Elnabaraway et al. [32] demonstrated that a sublethal Cd concentration of $2.5 \mu \mathrm{g} / \mathrm{L}$ significantly reduced fecundity of reproducing $D$. magna in as early as 14 days of exposure.

\section{Effects on embryo development}

The observation of undeveloped embryos in the present study indicates the effect of Cd and $\mathrm{Zn}$ on embryo development. The effect is more likely due to $\mathrm{Cd}$ since a higher number of undeveloped embryos was found in the $\mathrm{Cd}-\mathrm{Zn}$ mixtures than in $\mathrm{Zn}$ alone (Fig. 7).

Fisher et al. [33] demonstrated that metals can directly adsorb onto developing embryos/neonates in the brood chamber and prevent embryo development. Another recent study investigating Cd embryotoxicity revealed that D. magna embryos experienced severe morphological defects after acute exposures to 60,80 , or $100 \mu \mathrm{g} / \mathrm{L} \mathrm{Cd}$ [34]. Neonates were observed to have many deformities which ranged from caudal spine malformations, to poorly developed carapaces, and no antennas or eyes [34]. Although the concentrations of Cd used in the study by Djekoun et al. [34] were between 1 and 2 orders of magnitude higher than the concentration of $\mathrm{Cd}$ used in the present study, it is clear that with the water chemistry of the present study, $1.5 \mu \mathrm{g} / \mathrm{L} \mathrm{Cd}$, with chronic exposure is sufficient to induce embryonic deformities.

In examining embryonic morphological alterations, the study conducted by Mittmann et al. [35] was used as a reference (Fig. 8). Embryos collected from $\mathrm{Cd}$ alone, and the Cd-Zn This article is protected by copyright. All rights reserved 
mixtures showed that the developing offspring experienced morphological deformities which translated either to the shutdown of mitotic cell division (early or late cleavage) (Fig. 8B, D); disruption of cellular arrangement and organization (gastrulation) (Fig. 8F, J), or complete prevention from further development beyond stage 5 (Fig. $8 \mathrm{H}$ ) in comparison to the control embryos which displayed normal cleavage, a higher degree of cellular arrangement, organization, and differentiation (Fig. 8A, C, E, G, I).

Noticeably, the results further demonstrate that embryos exposed to $\mathrm{Cd}$ alone only underwent early cleavage, giving rise to a morula (Fig. 8B, while embryos exposed to the $\mathrm{Cd}-\mathrm{Zn}$ mixture underwent late cleavage, giving rise to a blastula (Fig. 8D), gastrulation (Fig. 8F, J), or development to stage 5 (Fig. 8H). Although some embryos were able to form a blastula and initiate gastrulation, the blastomeres were totally disorganized or deformed, and conglomerated into a blob of cells (Fig. 8F, J). This suggests that at some degree the blastomeres lost their ability to successfully communicate, and were unable to faithfully arrange and organize themselves. The effects of $\mathrm{Cd}$ on the morphological development of D. magna could be due to the disruption of biochemical signals that are essential to the successful development of $D$. magna embryos or it could be acting as a genotoxic agent that leads to the premature death of the developing embryos. Filipic and Hei [36] reported that $\mathrm{Cd}$ has high mutagenic activity since it predominantly induces large deletion mutations. In addition, $\mathrm{Cd}$ is able to interact with reactive oxygen species (ROS), disrupting cellular signaling and interfering with DNA repair [36].

Since $\mathrm{Cd}$ and $\mathrm{Zn}$ inhibit Ca uptake, these metals might have disrupted calcium homeostasis, and altered Ca-dependent cellular signaling. Cytoplasmic Ca signaling is known to regulate genes associated with differentiation, growth, and apoptosis, and disruption of those signaling pathways would lead to deleterious effects, including DNA impairment, transcriptional This article is protected by copyright. All rights reserved 
abnormalities, and malignant cellular growths [37]. Cadmium is able to inappropriately activate Protein Kinase $\mathrm{C}(\mathrm{PKC})$ at $\mathrm{nM}$ concentrations, but also reversibly, inhibit its activity at $\mu \mathrm{M}$ concentrations $[38,39]$. In addition, $\mathrm{Cd}$ can also replace the $\mathrm{Ca}^{2+}$ ion on Ca-dependent signaling proteins and disrupt the normal functions of those proteins [40]. For example, calmodulin, another Ca dependent signaling protein, is able to strongly bind to, modify, and interact with many target proteins, including kinases and phosphatases inducing several cellular signaling pathways [41]. These cellular effects are central to the toxic mechanisms of $\mathrm{Cd}$.

It is interesting to mention that at concentrations of $40,80,120 \mu \mathrm{g} / \mathrm{L}, \mathrm{Zn}$ protected adult D. magna from Cd toxicity (Fig. 1). The protective effect by a metal against toxic effect by another metal to aquatic organisms is attributed to a competitive binding mechanism at the biotic ligand $[1,26]$. However, there was no significant reduction in the percentage of undeveloped embryos in the mixtures compared to $\mathrm{Cd}$ alone (Fig. 7). This indicates that $\mathrm{Zn}$ did not have a protect effect on embryonic development in the mixtures. On the other hand, the percentage of undeveloped embryos were higher in the mixtures than their corresponding $\mathrm{Zn}$ alone treatment, signifying that $\mathrm{Cd}$ still plays a major role in affecting embryonic development in the mixtures. The effect on embryonic development could be due to accumulated $\mathrm{Zn}$ and $\mathrm{Cd}$ in D. magna. When looking at metal uptake at these water $\mathrm{Zn}$ concentrations, we found that body $\mathrm{Zn}$ concentration increased while body Cd concentrations in adult D. magna decreased (Fig. 11). Nevertheless, even with higher concentration of $\mathrm{Zn}$ accumulation in the body, low concentration of Cd still had a negative influence on embryonic development. This raises a question of whether competitive binding plays a major role in modifying impairment of embryonic development.

This article is protected by copyright. All rights reserved 


\section{CONCLUSIONS AND SUGGESTIONS}

Given the water chemistry parameters used in the present study, with optimal water $\mathrm{Zn}$ concentrations ranging from 40 to $120 \mu \mathrm{g} / \mathrm{L} ; \mathrm{Zn}$ protected D. magna from the chronic toxicity of $\mathrm{Cd}$, resulting in less-than-additive effects on survival, growth and reproduction. Zinc concentrations that are outside of the optimal range can either be insufficient to protect the organisms from $\mathrm{Cd}$ toxicity or join the toxic effects of $\mathrm{Cd}$. In general, when water $\mathrm{Zn}$ concentration increased, body $\mathrm{Zn}$ concentration increased and body $\mathrm{Cd}$ concentrations decreased. This explains the protective effect of $\mathrm{Zn}$ from $\mathrm{Cd}$ toxicity due to competitive binding mechanism between $\mathrm{Cd}$ and $\mathrm{Zn}$ at the biotic ligand. However, $\mathrm{Cd}$ affected embryonic development of $D$. magna regardless of the presence of $\mathrm{Zn}$ in the water or in the organisms. This embryonic effect is not explained by the competitive binding mechanism at the biotic ligand and raises a question of whether competitive binding plays a major role in modifying impairment of embryonic development? More studies should be conducted to characterize the interactive mechanisms between metals at the cellular level in organisms. Results of the present study are useful for development of metal mixture BLM and environmental quality guidelines.

Supplemental Data - The Supplemental Data are available on the Wiley Online Library at DOI: 10.1002/etc.xxxx.

Acknowledgement-We are grateful to the scholarship provided by the Loyola Institute of Environmental Sustainability. We acknowledge the assistances of E. Reynolds, N. Ali, T. Trinh, and R. Kashyap in conducting the experiments. We also would like to thank T.E. O'Brien for his assistance with data analysis and S. Mitten for contributing valuable comments and suggestions. Data Availability—Data can be accessed via supplemental documents.

This article is protected by copyright. All rights reserved 


\section{REFERENCES}

1. Meyer SJ, Farley JK, Garman RE. 2015a. Metal Mixtures Modeling Evaluation Project: 1.Background. Environ Toxicol Chem 34.4: 726-740.

2. Norwood WP, Borgmann U, Dixon DG, Wallace A. 2003. Effects of metal mixtures on aquatic biota: A review of observations and methods. Hum Ecol Risk Assess 9:795-811.

3. Vijver MG, Elliot EG, Peijnenburg WJGM, De Snoo GR. 2011. Response prediction for organisms water-exposed to metal mixtures: A meta-analysis. Environ Toxicol Chem 30: 1482-1487.

4. Hare L. 1992. Aquatic insects and trace metals: Bioavailability, bioaccumulation, and toxicity. Crit Rev Toxicol 22: 327-369.

5. Bodar CWM, Van Der Sluis Voogt PA, Zandee DI 1988. Effects of Cadmium on consumption, assimilation and Biochemical parameters of Daphnia magna: Possible Implications for Reproduction. Comp Biochem Physiol 90C.2: 341-346.

6. U.S. Environmental Protection Agency. 2001. Update of ambient water quality criteria for cadmium. EPA-822-R-01-001. Final Report. Office of Water, Washington, DC.

7. Agency for Toxic Substances and Disease Registry (ATSDR). 2012. Toxicological Profile for Cadmium (Update). Public Health Service, U.S. Department of Health and Human Services, Atlanta, GA, USA.

8. Taylor MC, Demayo A, Taylor KW, Brungs WA. 1982. Effects of zinc on humans, laboratory and farm animals, terrestrial plants, and freshwater aquatic life. Crit Rev Environ Con 12.2: $113-181$.

9. U.S. Environmental Protection Agency. 1985. Ambient water quality criteria for zinc. EPA440/5-87-003. Final Report. Office of Water, Washington, DC.

This article is protected by copyright. All rights reserved 
10. Thorpe VJ, Lake PS. 1974. Toxicity bioassays of cadmium on selected freshwater invertebrates and the interactions of cadmium and zinc on the freshwater shrimp, Paratya tasmaniensis Rick. Aust J Mar Fresh Res 25: 97-104.

11. Borgmann U. 1980. Interactive effects of metals in mixtures on biomass production kinetics of fresh-water copepods. Can J Fish Aqua Sci 37: 1295-1302.

12. Shaw JR, Dempsey TD, Chen CY, Hamilton JW, Folt CL. 2006. Comparative toxicity of cadmium, zinc, and mixtures of cadmium and zinc to daphnids. Environ Toxicol Chem 25: $182-189$.

13. Meyer SJ, Ranville FJ, Pontasch M, Gorsuch WJ, Adams JW. 2015b. Acute toxicity of Binary and Ternary Mixtures of $\mathrm{Cd}, \mathrm{Cu}$ and $\mathrm{Zn}$ to Daphnia magna. Environ Toxicol Chem 34.4: 799-808.

14. De Laender F, Janssen CR, De Schamphelaere KAC. 2009. Non-simultaneous Ecotoxicity testing of single chemicals and their mixture results in erroneous conclusions about the joint action of the mixture. Chemosphere 76: 428-432.

15. U.S. Environmental Protection Agency. 2002. Short-term Methods for Estimating the Chronic Toxicity of Effluents and Receiving Waters to Freshwater Organisms. EPA-821R-02-013 $4^{\text {th }}$ edition. Office of Water, Washington, DC.

16. ASTM. 2012. Standard Guide for Conducting Daphnia magna Life-Cycle Toxicity Tests, E1193-97, ASTM International, West Conshohocken, PA, USA.

17. Eaton, AD, Clesceri, LS, Greenberg, AE, Rice, EW. 2005. Standard Methods for the Examination of Water andWastewater, twenty-first ed. American Public Health Association. United Book Press Inc, Baltimore, Maryland, USA.

This article is protected by copyright. All rights reserved 
18. U.S. Environmental Protection Agency. 1996. Method 3050B: Acid Digestion of Sediments, Sludges, and Soils, Revision 2. https://www.epa.gov/sites/production/files/201506/documents/epa-3050b.pdf

19. Cañizares-Villanueva RO, Martínez-Jerónimo, Espinosa-Chávez F. 2000. Acute toxicity to Daphnia magna of effluents containing $\mathrm{Cd}, \mathrm{Zn}$, and a mixture $\mathrm{Cd}-\mathrm{Zn}$, after metal removal by Chlorella vulgaris. Environ Toxicol 15: 160-164.

20. Attar EN, Maly EJ. 1982. Acute toxicity of cadmium, zinc, and cadmium-zinc mixtures to Daphnia magna. Arch Environ Contam Toxicol 11: 291-296.

21. Spehar RL, Leonard EN, DeFoe DL. 1978. Chronic effects of cadmium and zinc mixtures on flagfish (Jordanella floridae). Trans Amer Fish Soc 107: 354-360.

22. Wicklund GA, Haux C, Hogstrand C. 1992. Chronic toxicity and metabolism of Cd and Zn in juvenile minnows (Phoxinus phoxinus) exposed to a $\mathrm{Cd}$ and $\mathrm{Zn}$ mixture. Can J Fish Aqua Sci 49: 2070-2079.

23. Lavoie M, Fortin C, Campbell PGC. 2012a. Extending the biotic ligand model to account for positive and negative feedback interactions between cadmium and zinc in a freshwater alga. Environ Sci Technol 46.21: 12129-12136.

24. Lavoie M, Fortin C, Campbell PGC. 2012b. Influence of essential elements on cadmium uptake and toxicity in a unicellular green alga: The protective effect of trace zinc and cobalt concentrations. Environ Toxicol Chem 31: 1445-1452.

25. Mebane CA, Dillon FS, Hennessy DP. 2012. Acute toxicity of cadmium, lead, zinc, and their mixtures to stream-resident fish and invertebrates. Environ Toxicol Chem 31: 1334-1348.

26. Santore RD, Ryan AC. 2015. Development and application of a multimetal multibiotic ligand model. Environ Toxicol Chem 34:777-787.

This article is protected by copyright. All rights reserved 
27. Komjarova I, Blust R. 2008. Multi-metal interactions between $\mathrm{Cd}, \mathrm{Cu}, \mathrm{Ni}, \mathrm{Pb}$, and $\mathrm{Zn}$ in water flea Daphnia magna, a stable isotope experiment. Aqua Toxicol 90: 138-144.

28. Benson A, Pylypczak M, Hoang TC. 2013. Protective effect of nickel and zinc from cadmium toxicity and uptake in Daphnia magna. SETAC North America $34^{\text {th }}$ Annual Meeting, Nashville, Tennessee, Nov. 17-21, 2013.

29. Yu RQ, Wang WX. 2002. Trace metal assimilation and release budget in Daphnia magna. Limnol Oceano gr 47: 495-504.

30. Bodar CWM, Van Leeuwen CJ, Voogt PA, Zandee DI. 1988. Effect of Cadmium on the reproduction strategy of Daphnia magna. Aqua Toxicol 12.4: 301-310.

31. Jemec A, Drobne D, Tišler T, Trebše P, Roš M, Sepčić K. 2007. The applicability of acetylcholinesterase and glutathione S-transferase in Daphnia magna toxicity test. Comp Biochem Physiol Part C: Toxicol Pharmacol 144.4: 303-309.

32. Elnabaraway M T, Welter AN, Robideau RR. 1986. Relative sensitivity to three daphnid species to selected organic and inorganic chemicals. Environ Toxicol Chem 5.4: 393-398.

33. Fisher NS, Stupakoff I, Sanudo-Wihelmy S, Wang WX, Teyssie JL, Fowler SW, Crusius J. 2000. Trace metals in marine copepods: A field test of a bioaccumulation model coupled to laboratory uptake kinetics data. Mar Ecol Prog Ser 194: 211-218.

34. Djekoun M, Bensoltane S, Bourechrouche A, Bourechrouche M, Berrebah H. 2015. In-vitro toxicity of cadmium on the development of parthenogenetic eggs of a freshwater cladoceran: Daphnia magna. J Mat Environ Sci 6.4: 957-962.

35. Mittmann B, Ungerer P, Klann M, Stollewerk A, Wolff C. 2014. Development and staging of the water flea Daphnia magna (Straus, 1820; Cladocera, Daphniidae) based on morphological landmarks. EvoDevo 5.1: 1-20.

This article is protected by copyright. All rights reserved 
36. Filipič M, Hei TK. 2004. Mutagenicity of cadmium in mammalian cells: implication of oxidative DNA damage. Mutat Res-Fund Mol M 546.1-2: 81-91.

37. Kasprzak KS, Salnikow K. 2007. Nickel Toxicity and Carcinogenesis, in Nickel and Its Surprising Impact in Nature. Volume 2, (eds. A. Sigel, H. Sigel and R. K. O. Sigel), John Wiley \& Sons, Ltd, Chichester, UK, pgs. 621-645. DOI: 10.1002/9780470028131.ch17.

38. Saijoh K, Inoue Y, Ratsuyama H, Sumino K. 1988. The interaction of cations with activity of soluble protein kinase C from mouse brain. Pharmacol Toxicol 78: 193-199.

39. Long GJ. 1997. The effects of Cadmium on cytosolic free calcium, protein kinase C, and collagen synthesis in rat osteosarcoma (ROS 17/2.8) cells. Toxicol Appl Pharmacol 43: 189-195.

40. Shafer TJ. 2000. The Role of Ion Channels in the Transport of Metals into Excitable and Nonexcitable Cells, in Molecular Biology and Toxicology of Metals. $1^{\text {st }}$ edition, (eds. Zalups R.K. and Koropatnick J.). Tailor and Francis Group, London and New York, pgs. 179-197. ISBN-0-7484-0798-7.

41. Chin D, Means AR. 2000. Calmodulin: a prototypical calcium sensor. Trends Cell Biol 10.8: 322-328.

This article is protected by copyright. All rights reserved 


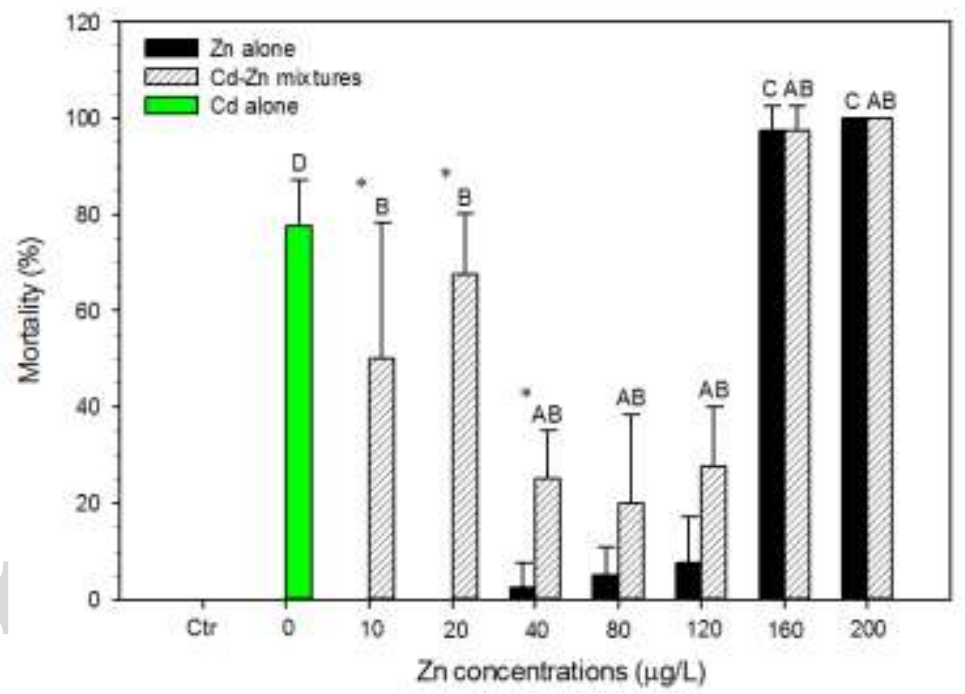

Fig. 1. 21-d cumulative mortality of D. magna due to exposure to $\mathrm{Cd}$ alone, $\mathrm{Zn}$ alone, and $\mathrm{Cd}-\mathrm{Zn}$ mixtures containing constant $\mathrm{Cd}$ concentration of $1.5 \mu \mathrm{g} / \mathrm{L}$ and varied $\mathrm{Zn}$ concentrations. A: significant differences between $\mathrm{Cd}$ alone and $\mathrm{Cd}-\mathrm{Zn}$ mixtures $(p<0.01)$. B: significant differences between control and $\mathrm{Cd}-\mathrm{Zn}$ mixtures $(p<0.001)$. C: significant differences between control and $\mathrm{Zn}$ alone $(p<0.001)$. D: significant difference between control and Cd alone $(p<0.001)$. *significant differences between $\mathrm{Zn}$ alone and $\mathrm{Cd}-\mathrm{Zn}$ mixtures $(p<0.05)$.

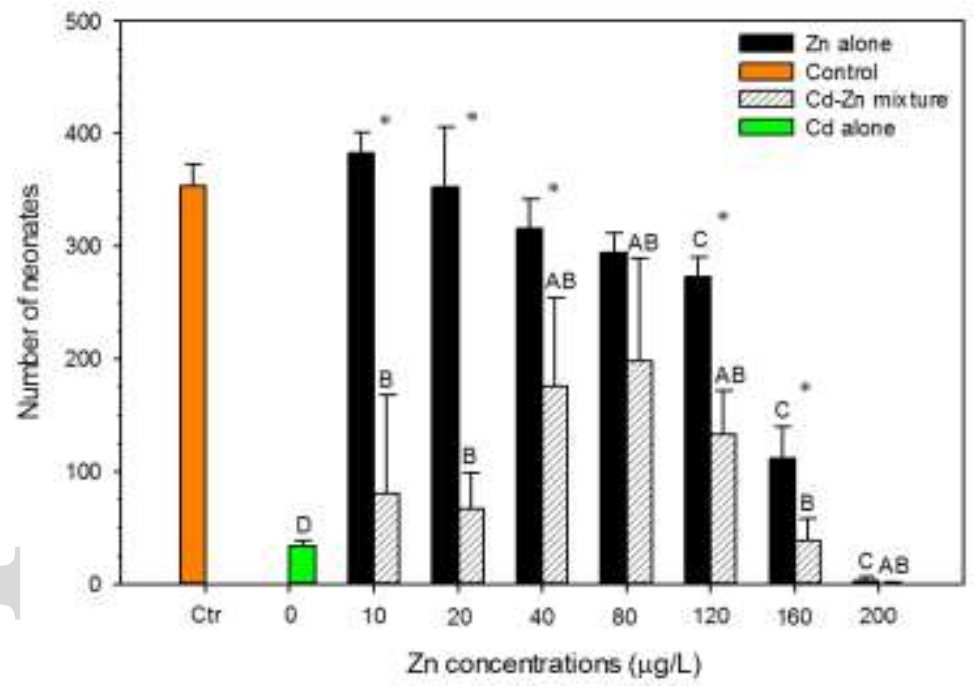

Fig. 2. Total neonates (dead and live) reproduced over 21-d of exposure to $\mathrm{Cd}$ alone, $\mathrm{Zn}$ alone, and $\mathrm{Cd}-\mathrm{Zn}$ mixtures containing constant $\mathrm{Cd}$ concentration of $1.5 \mu \mathrm{g} / \mathrm{L}$ and varied $\mathrm{Zn}$ concentrations. A: significant differences between $\mathrm{Cd}$ alone and $\mathrm{Cd}-\mathrm{Zn}$ mixtures $(p<0.05)$. B: significant differences between control and $\mathrm{Cd}-\mathrm{Zn}$ mixtures $(p<0.05)$. C: significant differences between control and $\mathrm{Zn}$ alone $(p<0.05)$. D: significant difference between control and Cd alone $(p<0.001)$.*significant differences between $\mathrm{Zn}$ alone and $\mathrm{Cd}-\mathrm{Zn}$ mixtures $(p<0.05)$. 


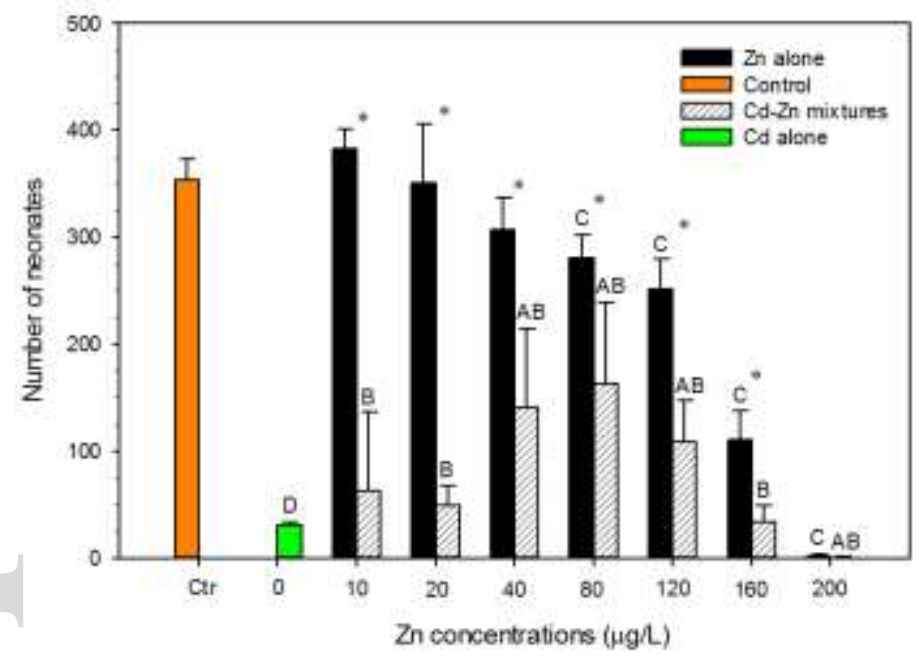

Fig. 3. Total live neonates reproduced over 21-d of exposure to $\mathrm{Cd}$ alone, $\mathrm{Zn}$ alone, and $\mathrm{Cd}-\mathrm{Zn}$ mixtures containing constant $\mathrm{Cd}$ concentration of $1.5 \mu \mathrm{g} / \mathrm{L}$ and varied $\mathrm{Zn}$ concentrations. A: significant differences between $\mathrm{Cd}$ alone and $\mathrm{Cd}-\mathrm{Zn}$ mixtures $(p<0.05)$. B: significant differences between control and $\mathrm{Cd}-\mathrm{Zn}$ mixtures $(p<0.01)$. C: significant differences between control and $\mathrm{Zn}$ alone $(p<0.05)$. D: significant difference between control and $\mathrm{Cd}$ alone $(p<0.001)$. *significant differences between $\mathrm{Zn}$ alone and $\mathrm{Cd}-\mathrm{Zn}$ mixtures $(p<0.01)$.

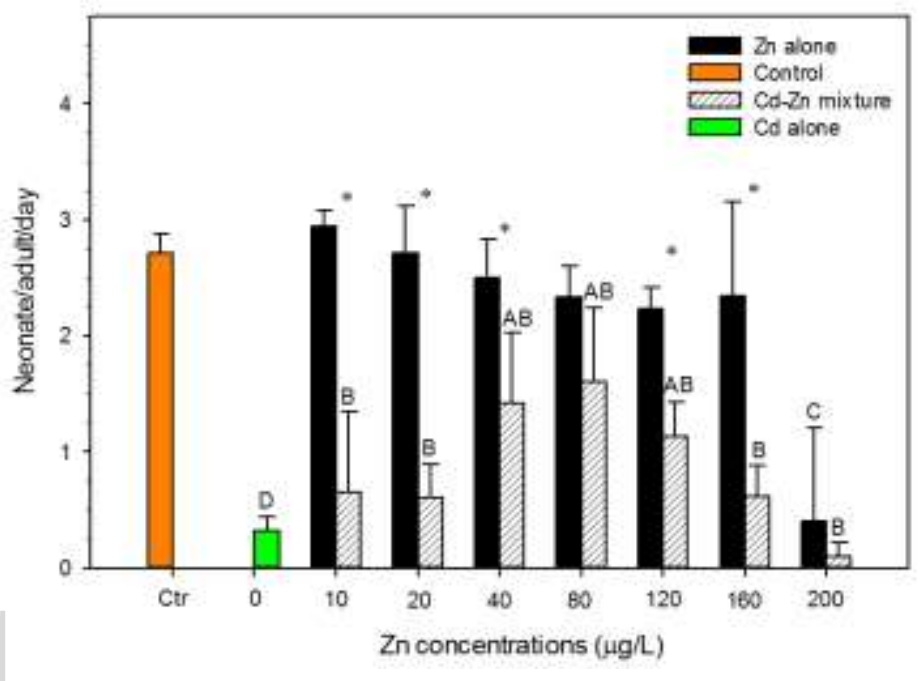

Fig. 4. Overall reproductive rate (dead + live neonates) of D. magna when exposed to Cd alone, $\mathrm{Zn}$ alone, and $\mathrm{Cd}-\mathrm{Zn}$ mixtures containing constant $\mathrm{Cd}$ concentration of $1.5 \mu \mathrm{g} / \mathrm{L}$ and varied $\mathrm{Zn}$ concentrations. A: significant differences between $\mathrm{Cd}$ alone and $\mathrm{Cd}-\mathrm{Zn}$ mixtures $(p<0.05)$. B: significant differences between control and $\mathrm{Cd}-\mathrm{Zn}$ mixtures $(p<0.05)$. C: significant differences between control and $\mathrm{Zn}$ alone $(p<0.05)$. D: significant difference between control and Cd alone $(p<0.001)$. *significant differences between $\mathrm{Zn}$ alone and $\mathrm{Cd}-\mathrm{Zn}$ mixtures $(p<0.05)$. 


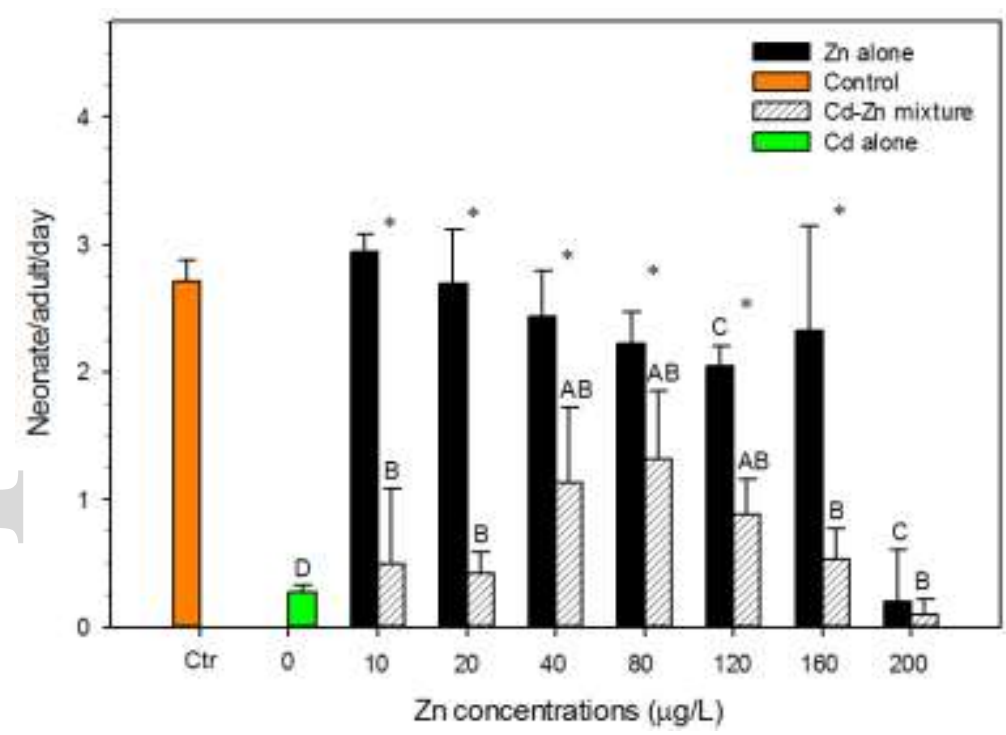

Fig. 5. Reproductive rate (live neonates) of D. magna when exposed to $\mathrm{Cd}$ alone, $\mathrm{Zn}$ alone, and $\mathrm{Cd}-\mathrm{Zn}$ mixtures containing constant $\mathrm{Cd}$ concentration of $1.5 \mu \mathrm{g} / \mathrm{L}$ and varied $\mathrm{Zn}$ concentrations. A: significant differences between $\mathrm{Cd}$ alone and $\mathrm{Cd}-\mathrm{Zn}$ mixtures $(p<0.05)$. B: significant differences between control and $\mathrm{Cd}-\mathrm{Zn}$ mixtures $(p<0.01)$. C: significant differences between control and $\mathrm{Zn}$ alone $(p<0.05)$. D: significant difference between control and $\mathrm{Cd}$ alone $(p<0.001)$. *significant differences between $\mathrm{Zn}$ alone and Cd-Zn mixtures $(p<0.05)$.

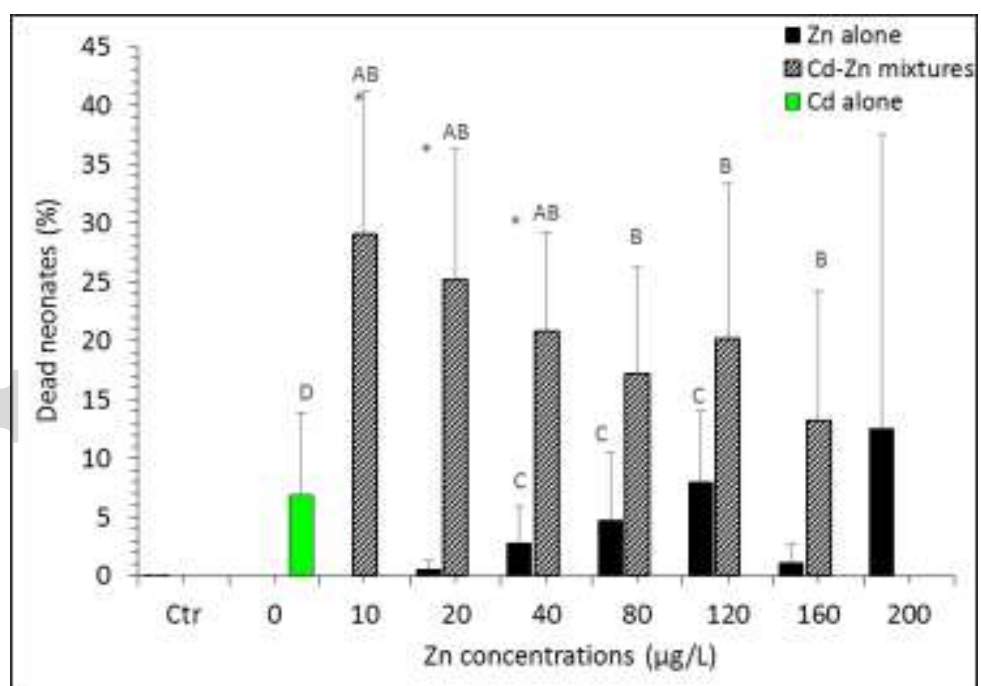

Fig. 6. Percent of dead neonates reproduced over 21-d of exposure to $\mathrm{Cd}$ alone, $\mathrm{Zn}$ alone, and $\mathrm{Cd}-\mathrm{Zn}$ mixtures containing constant $\mathrm{Cd}$ concentration of $1.5 \mu \mathrm{g} / \mathrm{L}$ and varied $\mathrm{Zn}$ concentrations. A: significant differences between $\mathrm{Cd}$ alone and $\mathrm{Cd}-\mathrm{Zn}$ mixtures $(p<0.05)$. B: significant differences between control and Cd-Zn mixtures $(p<0.05)$. C: significant differences between control and $\mathrm{Zn}$ alone $(p<0.05)$. D: significant difference between control and $\mathrm{Cd}$ alone $(p<0.05)$. *significant differences between $\mathrm{Zn}$ alone and Cd-Zn mixtures $(p<0.05)$. 


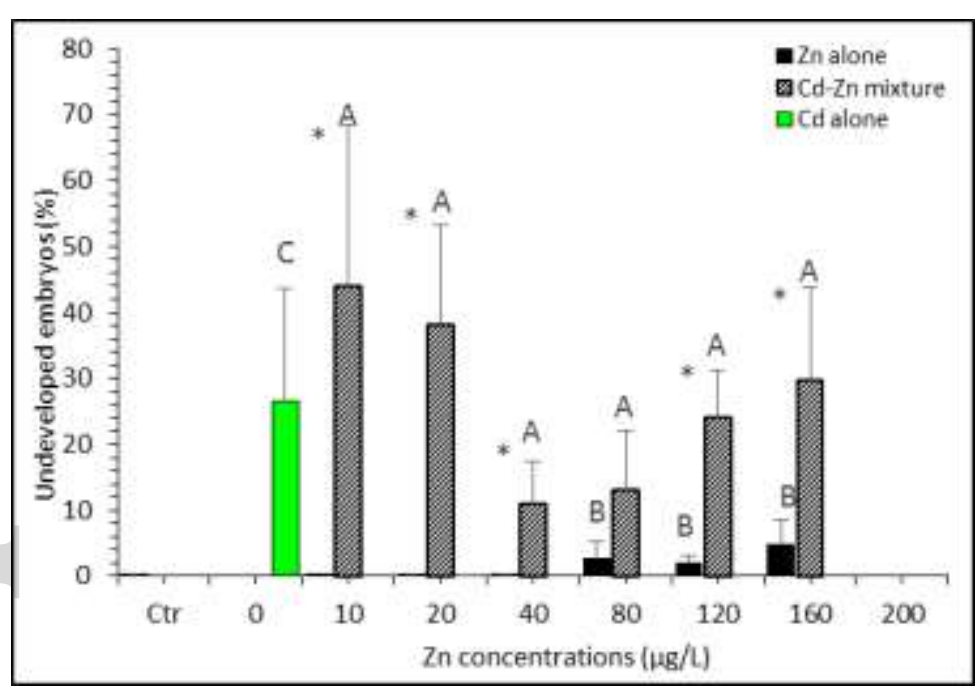

Fig. 7. Percent of undeveloped embryos observed over 21-d of exposure to $\mathrm{Cd}$ alone, $\mathrm{Zn}$ alone, and Cd$\mathrm{Zn}$ mixtures containing constant $\mathrm{Cd}$ concentration of $1.5 \mu \mathrm{g} / \mathrm{L}$ and varied $\mathrm{Zn}$ concentrations. A: significant differences between control and Cd-Zn mixtures $(p<0.01)$. B: significant differences between control and $\mathrm{Zn}$ alone $(p<0.05)$. C: significant difference between control and $\mathrm{Cd}$ alone $(p<0.05)$. *significant differences between $\mathrm{Zn}$ alone and $\mathrm{Cd}-\mathrm{Zn}$ mixtures $(p<0.05)$. 

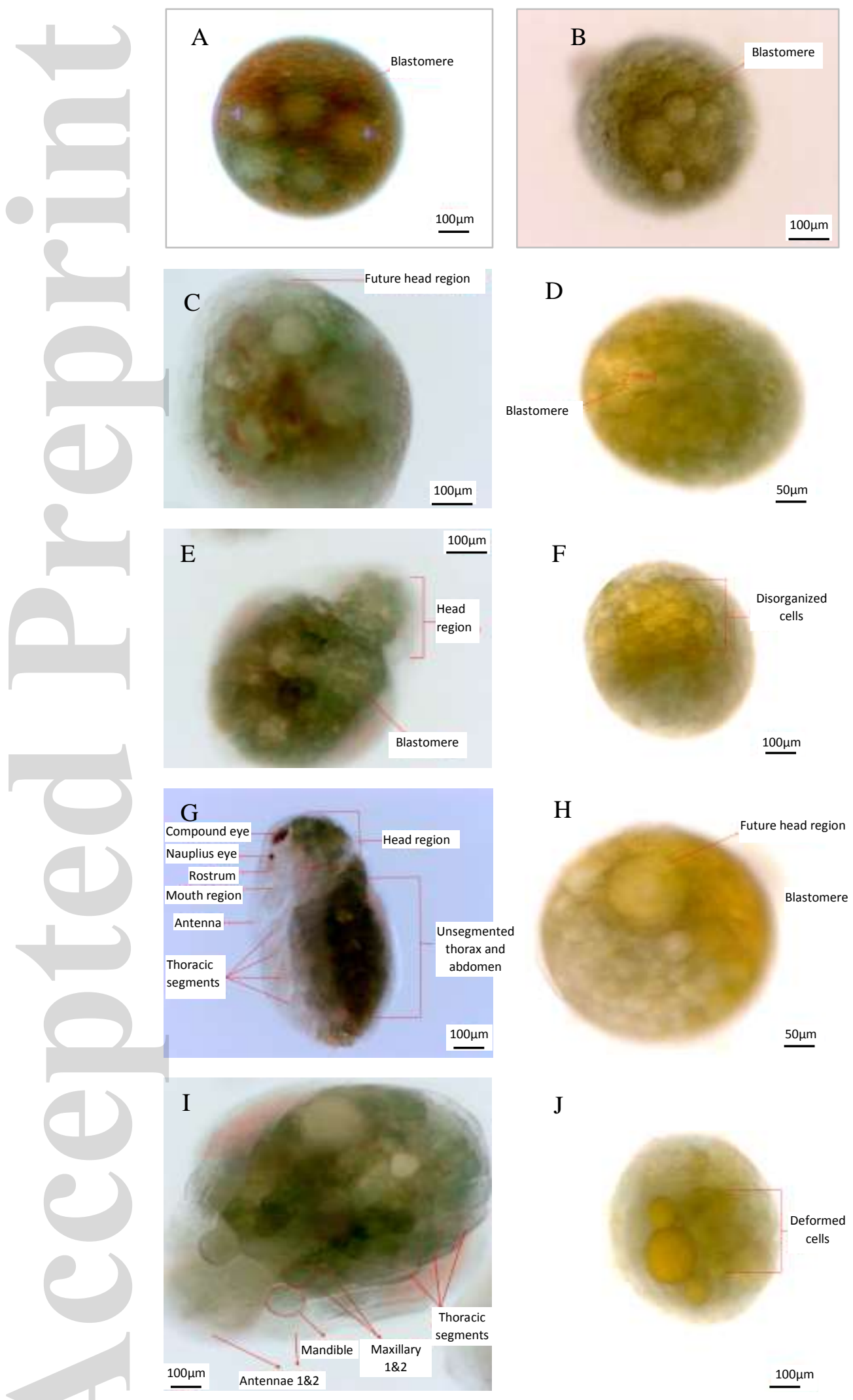
Fig. 8. Embryo development of D. magna over 10 stages.

A: Control embryo in stage 2 of development (early cleavage), B: Embryo in stage 2 of development (early cleavage) of $\mathrm{Cd}$ alone, C: Control embryo in stage 7.3 of development (Postnaupliar segments, ventral view), D: Embryo in stage 2 of development (late cleavage) for Cd-Zn mixture with $0 \mu \mathrm{g} / \mathrm{L} \mathrm{Zn}$, E: Control embryo in stage 9 of development (appearance of compound and nauplius eye, dorsal view), F: Embryo in stage 3 of development (gastrulation) for $\mathrm{Cd}-\mathrm{Zn}$ mixture at $20 \mu \mathrm{g} / \mathrm{L} \mathrm{Zn}, \mathrm{G}$ : Control embryo in stage 9 of development (lateral view), H: Embryo in stage 5 of development (head formation, anterodorsal view) for Cd-Zn mixture at $160 \mu \mathrm{g} / \mathrm{L} \mathrm{Zn}$. I: Control embryo in stage 10 of development (hook-shaped abdomen, ventral view), J: Embryo in stage 3 of development (gastrulation, ventral view) for Cd-Zn mixture at $40 \mu \mathrm{g} / \mathrm{L} \mathrm{Zn}$.

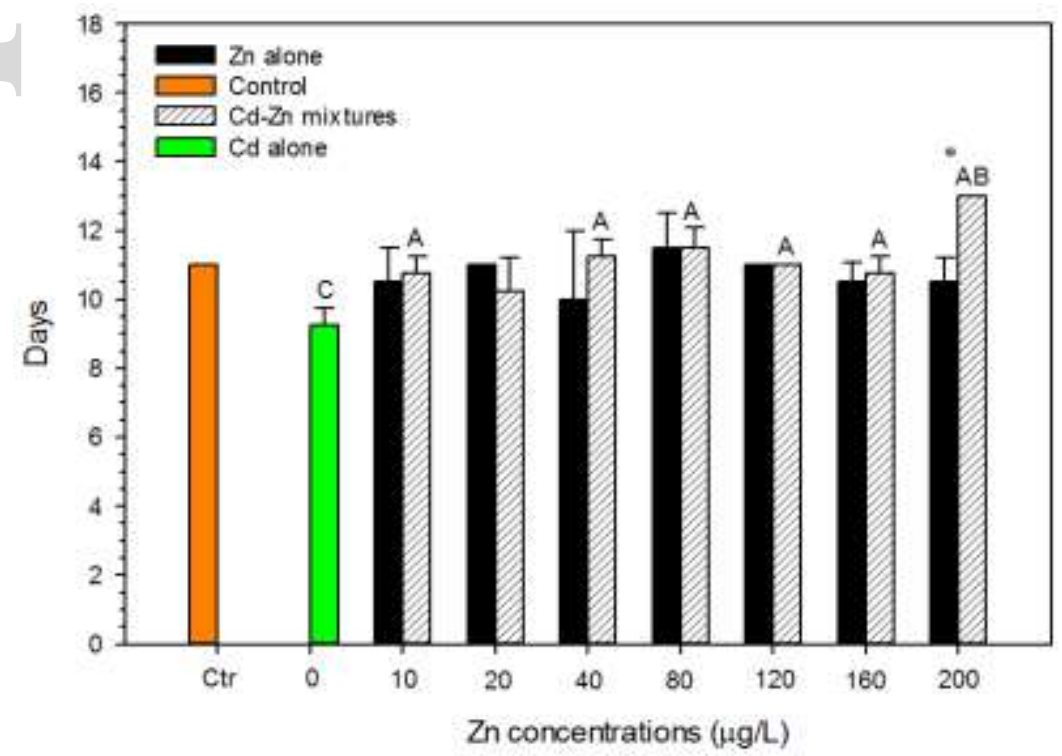

Fig. 9. Time to first brood over 21-d of exposure to $\mathrm{Cd}$ alone, $\mathrm{Zn}$ alone, and $\mathrm{Cd}-\mathrm{Zn}$ mixtures containing constant $\mathrm{Cd}$ concentration of $1.5 \mu \mathrm{g} / \mathrm{L}$ and varied $\mathrm{Zn}$ concentrations. A: significant differences between $\mathrm{Cd}$ alone and $\mathrm{Cd}-\mathrm{Zn}$ mixtures $(p<0.01)$. B: significant differences between control and $\mathrm{Cd}-\mathrm{Zn}$ mixtures $(p<0.01)$. C-significant differences between control and $\mathrm{Cd}$ alone $(p<0.01)$. *significant differences between $\mathrm{Zn}$ alone and $\mathrm{Cd}-\mathrm{Zn}$ mixtures $(p<0.01)$. 


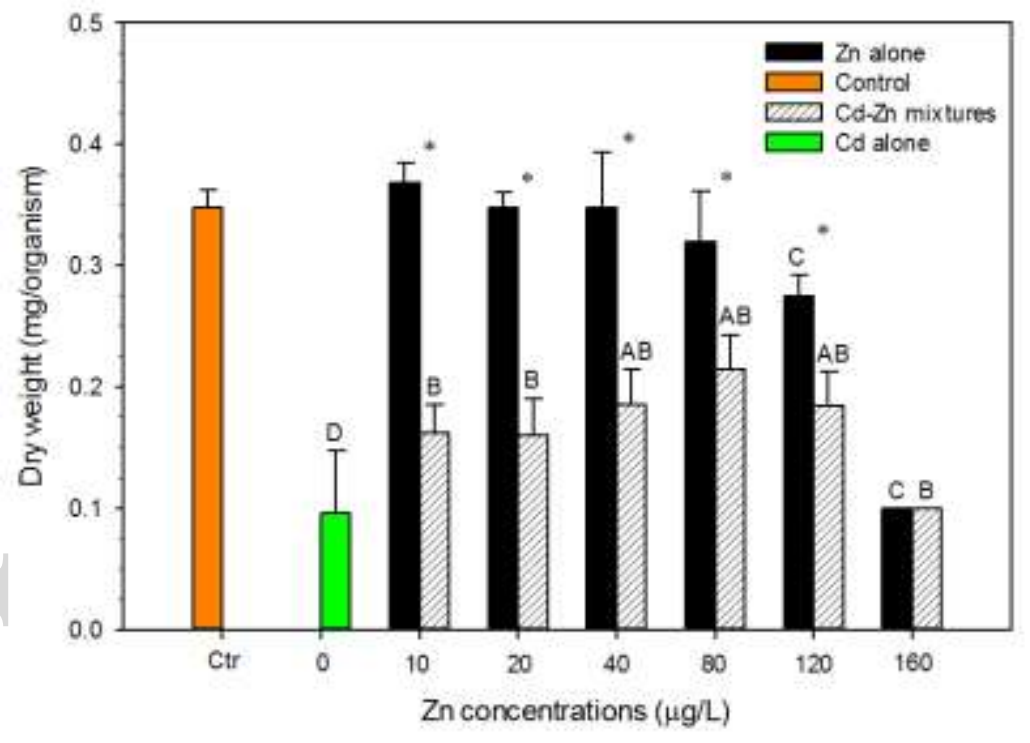

Fig. 10. Dry weight of surviving adults at test termination. A: significant differences between Cd alone and $\mathrm{Cd}-\mathrm{Zn}$ mixtures $(p<0.05)$. B: significant differences between control and $\mathrm{Cd}-\mathrm{Zn}$ mixtures $(p<0.05)$. C: significant differences between control and $\mathrm{Zn}$ alone $(p<0.05)$. D: significant difference between control and $\mathrm{Cd}$ alone $(p<0.001)$. *significant differences between $\mathrm{Zn}$ alone and $\mathrm{Cd}-\mathrm{Zn}$ mixtures $(p<0.01)$. 


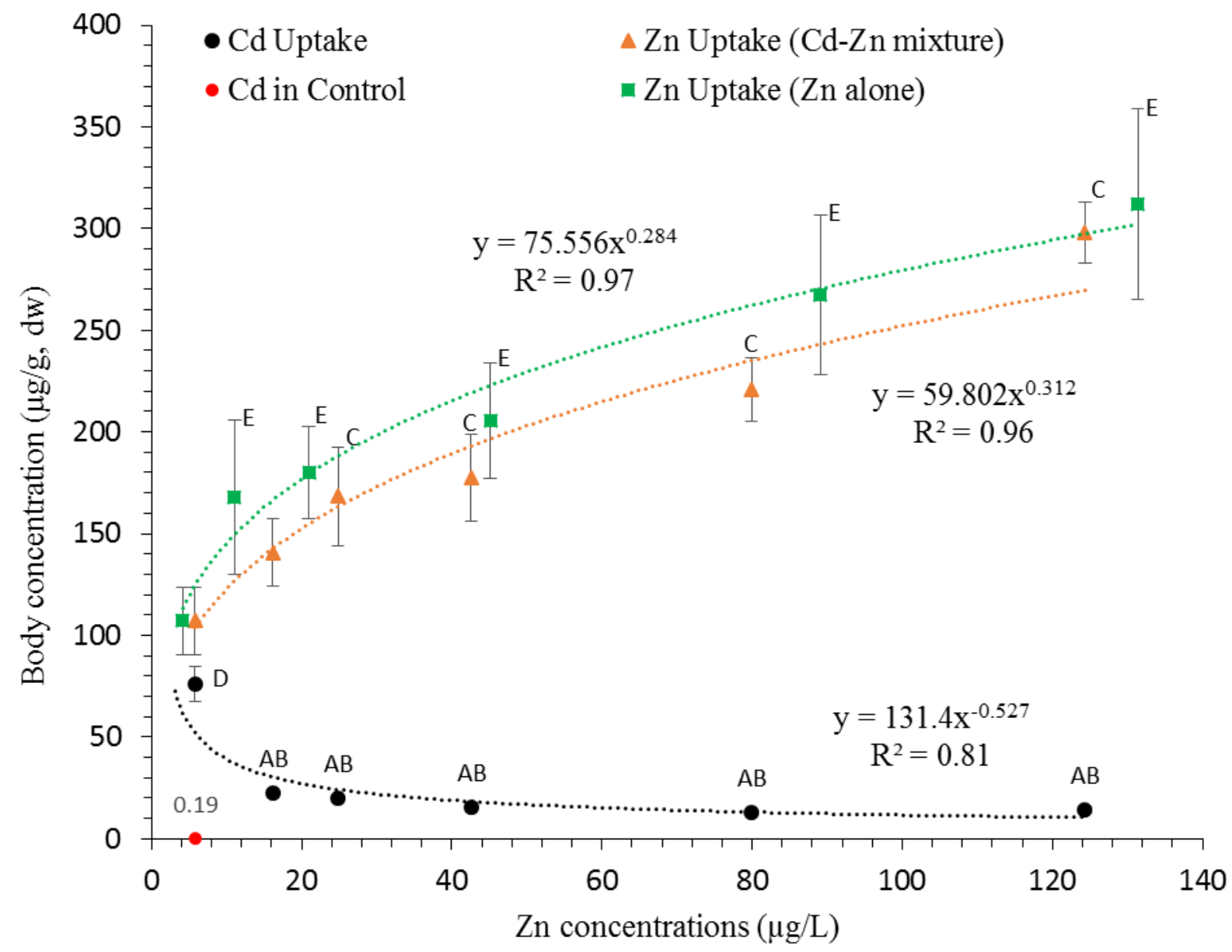

Fig. 11. Metal concentrations in the body of surviving daphnids exposed to $\mathrm{Zn}$ alone and $\mathrm{Cd}-\mathrm{Zn}$ mixture over 21 days. A: significant differences between $\mathrm{Cd}$ alone and $\mathrm{Cd}-\mathrm{Zn}$ mixtures $(p<0.05)$. B: significant differences between control and Cd-Zn mixtures $(p<0.05)$. C: significant differences between control and $\mathrm{Cd}-\mathrm{Zn}$ mixtures $(p<0.05)$. D: significant difference between control and $\mathrm{Cd}$ alone $(p<0.001)$. $\mathrm{E}$ : significant differences between $\mathrm{Zn}$ alone and control. 